\author{
Przemysław Sołga \\ (Pedagogical University of Krakow, Poland) \\ https://orcid.org/0000-0002-0670-8857 \\ E-mail: przemyslaw.solga@gmail.com
}

\title{
Główne płaszczyzny konfliktu Kościoła katolickiego z obozem piłsudczykowskim w Drugiej Rzeczypospolitej
}

\author{
The Main Points of Conflict Between the Catholic Church \\ and the Pro-Piłsudski Camp in Interwar Poland
}

\begin{abstract}
During the Second Polish Republic the Catholic Church and especially the church's higher hierarchy remained in constant conflict with the political supporters of Józef Piłsudski. This was the case for a number reasons, from Piłsudski's supporters' religious indifference, through their participation in freemasonic activities, liberal lifestyles, and leftist and socialist inclinations, up to their proneness towards totalitarianism, especially after 1926. A different aspect of the situation was the personal animosity between Marshall Piłsudski and various representatives of the clergy, who tended to support the opposing right-wing political forces. Despite this, the Pilsudski camp looked for a consensus with the church, and often undertook steps that were beneficial to it, as the camp was well aware of the church's influence. As a result some representatives of the church, including the Primate, were convinced that building an understanding was the only appropriate approach to the existing reality.
\end{abstract}

Key words: Pro-Piłsudski camp, Catholic Church, Second Polish Republic, conflict

\begin{tabular}{|c|c|c|c|c|}
\hline \multicolumn{5}{|c|}{ PUBLICATION INFO } \\
\hline$\left(\mathrm{IH} /{ }^{3}\right.$ & UMCS & * & $\begin{array}{l}\text { e-ISSN: } 2449-8467 \\
\text { ISSN: } 2082-6060\end{array}$ & OPEN OACCESS \\
\hline \multicolumn{5}{|c|}{$\begin{array}{l}\text { THE AUTHOR'S ADDRESS: Przemysław Sołga, Institute of History \& Archival Studies of the Pedagogical University } \\
\text { of Krakow, } 2 \text { Podchorążych Street, Kraków 30-084, Poland }\end{array}$} \\
\hline \multicolumn{5}{|c|}{ SOURCE OF FUNDING: Financed from the author's own funds } \\
\hline \multicolumn{2}{|l|}{$\begin{array}{l}\text { SUBMITTED: } \\
2019.09 .13\end{array}$} & $\begin{array}{l}\text { ACCEPTED: } \\
2020.10 .22\end{array}$ & $\begin{array}{l}\text { PUBLISHED ONLINE: } \\
2021.06 .30\end{array}$ & \\
\hline \multicolumn{3}{|c|}{$\begin{array}{l}\text { WEBSITE OF THE JOURNAL: } \\
\text { https://journals.umcs.pl/rh }\end{array}$} & $\begin{array}{l}\text { EDITORIAL } \\
\text { COMMITTEE E-mail: } \\
\text { reshistorica@umcs.pl }\end{array}$ & ef \\
\hline
\end{tabular}




\section{STRESZCZENIE}

Kościół katolicki w Drugiej Rzeczypospolitej, a konkretnie większość przedstawicieli jego wyższego duchowieństwa, pozostawał w stałym konflikcie z obozem politycznym Józefa Piłsudskiego. Składały się na niego takie czynniki, jak indyferentyzm religijny członków obozu piłsudczykowskiego, ich przynależność do masonerii, rozwiązłość w życiu prywatnym, lewicowe i socjalistyczne inklinacje oraz posługiwanie się $\mathrm{w}$ kulturze politycznej instrumentami typowymi dla państwa totalitarnego, zwłaszcza po roku 1926. Osobny aspekt stanowiły osobiste animozje Marszałka z poszczególnymi przedstawicielami kleru oraz poparcie, jakie ci ostatni wyrażali w stosunku dla konkurencyjnych opcji politycznych o odchyleniu prawicowym. Mimo wszystko obóz piłsudczykowski szukał konsensusu z Kościołem katolickim w Polsce, zdając sobie sprawę z jego wpływów i częstokroć podejmował działania idące na jego korzyść. Także niektórzy przedstawiciele polskiego episkopatu, z prymasem na czele, wychodzili z założenia, że w zaistniałej sytuacji jedynym stosownym rozwiązaniem jest szukanie wspólnej nici porozumienia z obozem rządzącym w Polsce.

Słowa kluczowe: Obóz piłsudczykowski, Kościół katolicki, Druga Rzeczpospolita, konflikt

\section{WSTĘP}

Obóz piłsudczykowski stanowił lewicowe skrzydło sceny politycznej w Polsce międzywojennej, co prowadziło nieuchronnie do konfliktu z Kościołem katolickim i przedstawicielami jego duchowieństwa. Choć relacje na tej linii w poszczególnych okresach przyjmowały różne konfiguracje, w zasadzie do końca istnienia Drugiej Rzeczypospolitej rysował się wyraźny antagonizm zachodzący pomiędzy piłsudczykami a przedstawicielami kleru, zwłaszcza tymi wchodzącymi w skład Episkopatu Polski. Celem artykułu jest ukazanie najważniejszych determinantów, które stanowiły czynniki implikujące wzajemną niechęć i wrogość zachodzącą pomiędzy przedstawicielami obozu piłsudczykowskiego i Kościoła katolickiego w Polsce międzywojennej.

W dotychczasowej historiografii brakuje opracowania, które ukazałoby tę tematykę $\mathrm{w}$ pełnym zakresie tematycznym i chronologicznym. Dostępne monografie i artykuły koncentrują się głównie na relacjach państwo-Kościół w okresie Drugiej Rzeczypospolitej, eksponując w sposób niepełny czynniki decydujące o konflikcie zachodzącym pomiędzy przedstawicielami obozu piłsudczykowskiego a Kościołem katolickim. Wyjaśnienie przyczyn i zrozumienie tego konfliktu nie jest możliwe bez ukazania kwestii aksjologicznych, nie zawsze wyrażanych expressis verbis przez obydwie strony, a niewątpliwie stanowiących o wzajemnej niechęci czy nawet wrogości. Religia i religijność, chrześcijańskie wartości, naród, wolność, w tym wolność gospodarcza, to wartości zajmujące poczesne 
miejsce w katolicyzmie. Piłsudczycy z kolei za nadrzędne wartości uznawali te, które sami często określali mianem „imponderabiliów”. Sprowadzały się one na ogół do dwóch zasadniczych: pierwszym było niepodległe państwo polskie, przeżywane bardzo emocjonalnie i stanowiące cel samo w sobie, drugim zaś odpowiedzialność moralna, jeśli chodzi o służbę państwu polskiemu, ciążąca na obywatelach, która wpływała modelująco na prowadzoną politykę i usprawiedliwiała takie działania, jak łamanie konstytucji, kontestacja demokracji, w tym swobód obywatelskich, czy też swobód poszczególnych grup społecznych oraz kategoryzacja obywateli i ich politycznych uprawnień w zależności od wyznawanych poglądów - legitymizując $\mathrm{w}$ ten sposób podejmowane decyzje $\mathrm{e}^{1}$. To właśnie kwestie aksjologiczne, zdaniem autora niniejszego opracowania, odegrały zasadniczą rolę $\mathrm{w}$ podniesionym $\mathrm{w}$ tytule konflikcie, determinując postawy poszczególnych duchownych, także przed uzyskaniem przez Polskę niepodległości, jak również po śmierci Józefa Piłsudskiego, co zostało zarysowane w niniejszym tekście, po raz pierwszy ukazującym tę tematykę przy stałym odniesieniu do „imponderabiliów” i ram chronologicznych, poczynając od I wojny światowej, a kończąc na ostatnich latach istnienia Drugiej Rzeczypospolitej.

Przede wszystkim już na samym wstępie należy przyjąć, że program polityczny i światopogląd większości przedstawicieli omawianego obozu był na ogół w dużym stopniu nie do pogodzenia z nauką chrześcijańską. W opinii wielu duchownych J. Piłsudski i jego poplecznicy jawili się jako „niebezpieczni radykałowie"2. Próbując znaleźć odpowiedź na pytanie, w jakich konkretnie aspektach ów radykalizm się przejawiał, należy odnieść się do poglądów i postaw, jakie prezentowali przedstawiciele obozu piłsudczykowskiego. Wzajemne relacje piłsudczyków i katolickiego kleru pogarszał fakt, że wielu z tych pierwszych w sferze prywatnej przyjmowało styl życia, który daleko odbiegał od chrześcijańskiego wzorca; powszechne były wśród nich rozwody czy też małżeństwa z rozwódkami, które pociągały za sobą częstokroć konwersję religijną z katolicyzmu na inne wyznanie. $W$ odniesieniu do spraw związanych $z$ religią cechowała ich na ogół obojętność ${ }^{3}$, choć nie to stanowiło główny czynnik antagonizujący wzajemne relacje. $Z$ pewnością większe znaczenie $w$ tym przypadku

1 W. Paruch, Myśl polityczna formacji piłsudczykowskiej w Polsce (1926-1939) - cechy podstawowe, "Annales Universitatis Mariae Curie-Skłodowska. Sectio K, Politologia” 2014, 21, 2, s. 127.

2 W.T. Kulesza, Koncepcje ideowo-polityczne obozu rzadzacego w Polsce w latach 1926-1935, Wrocław-Warszawa-Kraków-Gdańsk-Łódź 1985, s. 86.

3 P.A. Leszczyński, Stosunki państwo-Kościót w koncepcjach oraz praktyce rzadów obozu pitsudczykowskiego, Gorzów Wielkopolski 2008, s. 20. 
odgrywały kwestie światopoglądowe, odnoszące się do życia społeczno-politycznego i społeczno-gospodarczego.

Termin Kościół katolicki odnosi się w niniejszym opracowaniu do ogółu duchowieństwa katolickiego w Polsce międzywojennej, przede wszystkim zaś do przedstawicieli Episkopatu, jak również do osób i środowisk świeckich, które się z nim utożsamiały i dokonywały ocen, powołując się na katolicką naukę, przede wszystkim zaś do katolickich publicystów. Określenie „obóz piłsudczykowski” odnosi się do stronników J. Piłsudskiego, jego myśli politycznej i prowadzonej polityki w państwie, którzy starali się kontynuować swoje działania także po śmierci Marszałka.

\section{PIŁSUDCZYCY I ICH STOSUNEK DO RELIGII}

Jeśli chodzi o przekonania religijne, zdaniem ks. Józefa Dębińskiego, J. Piłsudski był na ogół deistą; można go też określić mianem „bezwyznaniowca” - „osoby, która siebie ustanowiła jako arbitra w sprawach wiary i moralności". Jego religijność nacechowana była skrytością dwuznacznością i liberalnościa, jednak nie było w niej oznak wrogości wobec wyznania katolickiego, protestanckiego czy też mojżeszowego ${ }^{4}$. Pewnym ewenementem, na przekór indyferentnego stosunku do religii był jego kult Matki Boskiej Ostrobramskiej, który wyniósł z rodzinnego domu. Kard. Aleksander Kakowski odniósł się niegdyś do niego w takich oto słowach: „co do istnienia Boga ma poważne wątpliwości, a jednocześnie do Matki Boskiej - gorące nabożeństwo" ${ }^{5}$. Wiesław Wysocki, za którym przytaczam te słowa, uzasadniał powyższą postawę jego specyficznym kultem maryjnym, który przesłaniał chrystologię i do niedawna był charakterystyczną cechą polskiego katolicyzmu. Niemniej polscy hierarchowie kościelni mieli świadomość, że J. Piłsudski osobą religijną nie był, co na pewno nie przysparzało mu popularności wśród kleru6 . Jednakowoż Marszałek otaczał się ludźmi, z których wielu miało antyklerykalne

4 J. Dębiński, Józef Piłsudski a Kościót katolicki w Polsce w latach 1918-1935, w: Józef Pitsudski wobec Europy i wybranych zagadnień wewnętrznych Drugiej Rzeczypospolitej (19181935). W 70. rocznicé śmierci, red. M. Wojciechowski, Z. Karpus, Włocławek-Torun 2007, s. 104-105.

5 Cyt. za: W. Wysocki, Konterfekt religijny Marszałka, „Periodyk Naukowy Akademii Polonijnej" 2015, 2, 13, s. 81.

6 Szerzej na ten temat zob. J. Warszawski, Studia nad wyznaniowościa religijna marszałka Józefa Piłsudskiego, Londyn 1978. 
poglądy; pojawiały się wśród nich postulaty rewizji konkordatu, sekularyzacji dóbr należących do Kościoła i laicyzacji życia publicznego ${ }^{7}$.

Do obozu piłsudczykowskiego polski kler zrażała przynależność wielu członków tego pierwszego do lóż masońskich. Polska Partia Socjalistyczna niemal od samych swoich początków utrzymywała pewne związki z wolnomularstwem. Masonami byli między innymi redaktor pisma socjalistycznego „Równość" Stanisław Mendelson czy publicysta Feliks Perl, jeden z liderów Frakcji Rewolucyjnej PPS po 1906 r. Wolnomularze związani z tą frakcją starali się wykorzystywać swoje znajomości w innych, zwłaszcza zagranicznych kręgach masońskich do realizacji postawionych przez siebie celów politycznych. Jeśli chodzi tylko o jeden z gabinetów Kazimierza Bartla, na 11 jego członków przypadało co najmniej 5 masonów ${ }^{8}$. Zdaniem Andrzeja Ajnenkiela fakt, iż znaleźli się oni we wspomnianym gabinecie, należy tłumaczyć tym, że należeli do kół, które przygotowywały zamach majowy ${ }^{9}$. Nie ulega wątpliwości, że został on przeprowadzony we współpracy z polskimi wolnomularzami. Na dodatek główne miejsce pobytu zamachowców ulokowane było w mieszkaniu Stanisława Patka - masona, który pozostawał wierny J. Piłsudskiemu. Jest także wielce wymowne, że pierwszym premierem w Polsce po zamachu majowym został Kazimierz Bartel, który także był masonem ${ }^{10}$. Wolnomularze jednakowoż przedsięwzięli antyklerykalne działania po dokonaniu zamachu stanu w 1926 r. Mieczysław Skrudlik pisał, że „dni walki ulicznej stolicy były próbą doraźnego załatwienia się z duchowieństwem katolickim”; i dalej: „wśród tłumów i żołnierzy widziano w tych pamiętnych dniach agitatorów, nawołujących do krwawej rozprawy z księżmi. Naczelne wskazanie masonerii, walka z Kościołem i duchowieństwem, uzewnętrzniło się [...] w całem, ponurem świetle"11. Andrzej Zwoliński wśród piłsudczyków-masonów wskazuje na takie postacie jak m.in.: „W. Sławek, B. Miedziński, A. Skwarczyński, B. Wieniawa-Długoszowski, bracia M. i N. Downarowicze. Spośród oficerów: A. Koc, J. Rzemiński i R. Górecki. W polskiej służbie dyplomatycznej działali m. in. wolnomularze: A. Zaleski, M. Arciszewski, T. Filipowicz, R. Knoll, H. Gliwic, S. Hempel, S. Patek, E. Kipa. [...] Z grona ówczesnych

7 K. Krasowski, Między Warszawa a Watykanem. Episkopat Polski wobec rzadu i stolicy apostolskiej 1918-1939, w: Szkice z dziejów papiestwa, t. 1, red. I. Koberdowa, J. Tazbir, Warszawa 1989, s. 91.

8 A. Ajnenkiel, Polska po przewrocie majowym. Zarys dziejów politycznych Polski 19261939, Warszawa 1980, s. 10.

9 Ibidem, s. 12.

10 A. Zwoliński, Polskie ścieżki masonerii, Kraków 2014, s. 111.

11 Cyt. za: P. Waingertner, Wolnomularstwo a Kościół katolicki w II Rzeczypospolitej. Kontrowersje i polemiki, „Acta Universitatis Lodziensis. Folia Historica” 1995, 52, s. 134. 
naukowców wolnomularzami byli m. in.: prof. K. Bartel (premier po przewrocie majowym), M. Wolfke, L. Kozłowski (późniejszy premier), M. Michałowicz, M. Konopacki i znany socjolog A. Hertz, prawnik S. Car (doradca prawny J. Piłsudskiego, w latach 1938-1939 minister sprawiedliwości, opracował Konstytucję kwietniową w 1935 r.), F. Paschalski, L. Berenson, L. Altberg". Masonami byli prezydenci: Gabriel Narutowicz, Bolesław Wieniawa-Długoszowski, Władysław Raczkiewicz, August Zaleski. W latach 1918-1926 czterech premierów było masonami, a po zamachu majowym aż do 1939 r. było takowych aż 13. Na 511 ministrów we wszystkich gabinetach II Rzeczypospolitej około 200 było w pewnym okresie swojego życia związanych z masonerią. Jednym z najwybitniejszych masonów w Polsce w dwudziestoleciu międzywojennym był Andrzej Strug (właśc. Tadeusz Gałecki). Był on aktywnym członkiem PPS, związanym konkretnie z PPS Lewicą. Należał do Pierwszej Brygady Legionów Polskich utworzonych przez J. Piłsudskiego. Otrzymawszy masońskie imię Stanisław Borszowski, aż do zamachu majowego był jednym jednym z jego bliższych współpracowników. Michał Sokolnicki przedstawił zadania stojące przed wolnomularstwem J. Piłsudskiemu, który jednak nie wykazał zainteresowania tą kwestią. Stosunek tego drugiego do wolnomularstwa jest po dzisiaj przedmiotem wielu kontrowersji w kręgach historyków. Marszałek formalnie do żadnej loży wolnomularskiej nie przystąpił, wiadomym jest jednak, że sprzyjał interesom wielu z nich. Jeszcze jako Naczelnik Państwa popierał działalność Wielkiej Loży Narodowej Polski, która miała wówczas największe znaczenie. Aprobował także działania organizacji masońskich, które był z nim konsultowa$n^{12}$. Radosława Radosik również podkreśla, że J. Piłsudski opiekował się masonami, i choć sam nie był jednym z nich, ze względu na cechy charakteru nazywano go masonem „masonem bez fartuszka” ${ }^{13}$. Trudno zatem zgodzić się z Tomaszem Serwatka, jakoby od wolnomularstwa J. Piłsudski „stanowczo się odcinał"14.

W Polsce międzywojennej Kościół wielokrotnie podnosił, że głównym celem działania masonerii była walka o laicyzację życia publicznego i społecznego, wprowadzenie tzw. laickiej moralności, obrona mniejszości narodowych przeciwstawiana tendencjom narodowym oraz próba pomniejszenia wpływów Kościoła na życie narodu ${ }^{15}$. Taki stan rzeczy

12 A. Zwoliński, Polskie, s. 108-115.

13 R. Radosik, Stereotyp masona w twórczości Skamandrytów, "Ars Regia. Czasopismo Poświęcone Myśli i Historii Wolnomularstwa" 2010, 12, 19, s. 136. Zob. także: L. Chajn, Wolnomularstwo i Piłsudski w 1921 r., "Zeszyty Historyczne” 1981, 55, s. 231-237.

14 T. Serwatka, Koncepcje społeczno-polityczne Prymasa Polski Augusta Hlonda 1926-1948, Poznań 2006, s. 15.

15 A. Zwoliński, Wokót masonerii, Kraków 1993, s. 39. 
spotykał się wielokrotnie z ostrymi replikami, wychodzącymi od katolickich duchownych. 17 lutego 1932 r. kard. A. Kakowski przemówił do pisarzy katolickich, wskazując na ich zadanie: „Obronę Kościoła oraz naszych tradycji i ideałów religijnych i narodowych przed napaściami i przewrotną działalnością masonerii, wolnomyślicielstwa, radykalizmu i sekciarstwa, które panoszą się i krzewią w Polsce, korzystając z wybujałej wolności"16. Podobnie głosy padały wielokrotnie $\mathrm{z}$ ust innych polskich biskupów.

\section{SOCJALISTYCZNE INKLINACJE OBOZU PIŁSUDCZYKOWSKIEGO}

Inną istotną kwestią był hołubiony przez Piłsudskiego socjalizm, będący nie do pogodzenia $\mathrm{z}$ katolicką nauką społeczną ${ }^{17}$. Wielu badaczy przychyla się do stanowiska, że stosunek J. Piłsudskiego do socjalizmu był raczej oględny. Nie uznawał walki klas i wszechwładnej roli państwa, a w ruchu robotniczym upatrywał przede wszystkim ścieżkę, którą Polska będzie kroczyć celem wywalczenia niepodległości, bowiem walka o niepodległość była wpisana w przedwojenny program PPS ${ }^{18}$. Andrzej Friszke uważa mimo wszystko, że J. Piłsudski był po prostu socjalistą i choć daleko mu było do ortodoksji marksistowskiej, to jednak czasem posługiwał się tą ideologia, by uzasadnić niektóre swoje poglądy ${ }^{19}$. Podobne uwagi można odnieść do przedstawicieli jego obozu politycznego: „piłsudczycy na ogół otarli się o PPS, byli radykałami społecznymi, nienawidzili endecji, sympatyzowali z lewica, a w partiach lewicowych wielu działaczy było jednocześnie piłsudczykami"20. Także Zbigniew Osiński zauważa, że lewicowe poglądy społeczne były jednym ze spoiw łączących piłsudczyków jako organizm polityczny ${ }^{21}$. $Z$ tych powodów nie mogli oni na pewno liczyć na to, że kler odniesie się pozytywnie do ich programu politycznego. Ksiądz Jan Urban, jezuita, wpływowy i cieszący się autorytetem redaktor naczelny „Przeglądu Powszechnego", zaznaczał, że socjalizm polski skupia się głównie wokół frakcji, jaką jest PPS. Zarzucał jej członkom ordynarne odnoszenie się do księży na łamach prasy i jawny antyklerykalizm, zaś "praktyczny stosunek do socjalizmu polskiego może być tylko negatywny i odporny. [...] Jako katolicy, ktokolwiek do

S. Wilk, Episkopat Kościoła katolickiego w Polsce w latach 1918-1939, Lublin 1992, s. 130.

Zob. P. Nitecki, Socjalizm, komunizm i ewangelizacja, Lublin 1998.

W.T. Kulesza, op. cit., s. 41.

19 A. Friszke, O kształt niepodległej, Kraków 1989, s. 44.

20 Ibidem, s. 229.

21 Z. Osiński, Janusza Jędrzejewicza droga do kariery w obozie pitsudczykowskim, "Annales Universitatis Mariae Curie-Skłodowska. Sectio F, Historia" 2006, 61, s. 159.
} 
Kościoła katolickiego szczerze się przyznaje, wszyscy bez względu na partyjną przynależność i interesy grupowe, musimy zwalczać socjalizm za jego wrogie stanowisko względem naszej religii, naszego Kościoła"22. Po odzyskaniu niepodległości przez Polskę w 1918 r. rozrastały się szybko stronnictwa lewicowe, stąd Kościół stanął przed naglącą potrzeba, aby zając bardziej zdecydowane stanowisko w kwestii społecznej. Odwołując się do nauczania Leona XIII, polscy hierarchowie kościelni wskazywali na solidaryzm społeczny, odnosili się z sympatią do modelu demokracji chrześcijańskiej. Stwierdzono ostatecznie, że nierówność społeczna jest czymś naturalnym; przestrzegano zarazem przed uleganiem manipulacyjnym i populistycznym hasłom, takim jak doprowadzenie do równości na podłożu ekonomicznym wszystkich grup społecznych ${ }^{23}$. Idąc w ślad za nauczaniem Stolicy Apostolskiej, po opublikowaniu encykliki Rerum novarum polscy duchowni zaczęli zajmować stanowisko w sprawie socjalizmu - początkowo czynili to biskupi w Królestwie Polskim, gdzie mieliśmy do czynienia z największym wysypem ugrupowań socjalistycznych ${ }^{24}$. Po ukazaniu się encykliki Leona XIII stało się jasne, że nie jest możliwy konsensus pomiędzy socjalizmem a katolicką doktryną społeczną. Wielu katolików, mimo wszystko, należało do stowarzyszeń socjalistycznych. Tłumaczyć to zjawisko można faktem, że wielu spośród nich było ludźmi niewykształconymi, niemającymi świadomości oficjalnej nauki Kościoła. Trzeba mieć także na uwadze propagandę partii socjalistycznych i treści przez nie przekazywane, jakimi byli indoktrynowani przedstawiciele religii katolickiej. Socjalistom wydawało się mimo wszystko, że socjalizm można pogodzić z katolickimi praktykami religijnymi. Znane są też słowa urzędującego wówczas papieża Piusa XI, które zawarł w encyklice wydanej z okazji czterdziestej rocznicy publikacji Rerum novarum: „nikt nie może być jednocześnie dobrym katolikiem i prawdziwym socjalistą"25.

Główny zarzut pod adresem socjalistów w polskich środowiskach katolickich podnosił problem moralności socjalistycznej. Szczególnie atakowano zasadę wolności seksualnej i subiektywnej moralności. Podkreślano przy tym, że Kościół nie piętnuje socjalistów jako ludzi, lecz zwalcza ich światopogląd. Socjaliści zarzucali Kościołowi wrogość wobec reform społecznych, bliskie związki z właścicielami i kapitalistami, chęć

\footnotetext{
22 J. Urban, Nasz stosunek do socjalizmu, „Przegląd Powszechny” 1927, 174, s. 329-330.

23 M. Stanulewicz, Prawo własności w nauczaniu episkopatu II Rzeczypospolitej, „Czasopismo Prawno-Historyczne" 2012, 64, s. 75.

24 R. Szczurowski, Socjaliści w polskiej publicystyce katolickiej 1878-1918, Kraków 2001, s. 35 .

25 Pius XI, encyklika Quadragesimo anno, nr 120.
} 
zdominowania i podporządkowania sobie wszystkich sfer życia świeckiego, brak tolerancji wobec innowierców i ludzi niewierzących. W ten sposób uzasadniali swoją wrogość wobec religii i szerzenie programowego ateizmu ${ }^{26}$. Na zarzuty o brak moralności socjaliści odpowiadali: „socjalizm jest wiara, która czyni ludzi lepszymi, gdyż wznosi ich ponad nich samych i wskazuje im cele ponad-osobowe"27.

Wśród katolickiej ludności polskiej było wielu takich, którzy nie zdawali sobie sprawy ze stanowiska Kościoła wobec socjalizmu i jawnie określali siebie mianem socjalistów. Duchowni katoliccy oczywiście dostrzegali zaistniałe zjawisko i wielokrotnie je krytykowali. Ksiądz Jan Piwowarczyk w 1924 r. pisał.: „,[...] jeszcze ciągle zdarzają się u nas takie anomalie, że wierzący katolik należy do zawodowych, a nawet politycznych organizacji socjalistycznych. Pochodzić to może jedynie z głupoty, z ignorancji, uświadomiony bowiem katolik, nawet prosty robotnik, nie orientujący się w filozofii socjalizmu, musi na każdym kroku spostrzegać, że zasady ruchu socjalistycznego sprzeciwiają się religii katolickiej! [...] Rzeczą katolickich towarzystw oświatowych i duchowieństwa będzie takie rozgraniczenie katolików od socjalistów popierać i szerzyć" ${ }^{28}$. Nie tyle jednak "nieuświadomiony robotnik" musiał zdawać sobie sprawę z tego, że „zasady ruchu socjalistycznego sprzeciwiają się religii katolickiej”, ile raczej jego dewizy i główne postępowania wymierzone są w Kościół jako instytucję oraz jego naukę.

\section{PAŃSTWO-CENTRYZM W IDEOLOGII PIŁSUDCZYKÓW}

Państwo-centryzm piłsudczyków także kłócił się z nauką Kościoła. Obóz J. Piłsudskiego nie uznawał wyższości narodu nad państwem, co pozostawało $\mathrm{w}$ sprzeczności z większością opinii duchowieństwa. Piłsudczycy nie dostrzegali znaku równości pomiędzy tymi dwiema wartościami; wierzyli w zasadę, że pomyślność narodu jest pochodną pomyślności państwa. Ich koncepcja narodu kłóciła się z tą endecką, która była o wiele bliższa przedstawicielom polskiego kleru: dla endecji naród to nie tyle wspólnota języka, powiązanych losów czy pochodzenia, ale wspólne działanie zbiorowości. Państwo w koncepcji J. Piłsudskiego i jego popleczników było instytucją ponadnarodową i nadrzędną wobec społecznych struktur i świadomości społeczeństwa. Jednocześnie podnosili oni wyższość interesu państwowego nad interesem jednostek czy

\footnotetext{
26 A. Zwoliński, Katolik i polityka, Kraków 1999, s. 196.

27 L. Kruczkowski, Dlaczego jestem socjalista?, Warszawa 1938, s. 8.

28 Cyt. za: R. Szczurowski, op. cit., s. 42.
} 
poszczególnych narodowości ${ }^{29}$, co także było nie do pogodzenia z personalizmem chrześcijańskim. Wedle piłsudczyków obywatela powinno się uznawać i oceniać nie jako jednostkę w ogóle, lecz zależnie „od jej wartości dla społeczeństwa" ${ }^{\prime 3}$. To nie indywiduum, ale kolektyw odgrywał zatem ich zdaniem zasadniczą rolę w życiu społecznym, a rola państwa nie ograniczała się do bycia jedną z kluczowych wartości, lecz było ono „najwyższym dobrem w życiu doczesnym” ${ }^{31}$. Kwestia niepodległości państwa czy też zaistnienia bytu państwowego była dla nich niemalże obsesją aż do 1918 r., w czym leży zapewne jedna z przyczyn późniejszego „ubóstwiania” państwowości jako czegoś, co zostało wywalczone z wielkim wysiłkiem po ponad stu latach zaborów. Niezrozumienie i brak poparcia, z jakimi się spotykali na terenie Kongresówki w czasie I wojny światowej, stanowiło preludium do późniejszych animozji na gruncie światopoglądowym.

Nic zatem dziwnego, że piłsudczykowska koncepcja znaczenia państwa kolidowała z wizją polskiego duchowieństwa, które wartości narodowe stawiało wyżej. Stosunek polskiego Episkopatu do kwestii związanych z narodem jako wartością dobrze odzwierciedlał prymas Polski August Hlond, dla którego czynnikiem konstytuującym państwo był zawsze naród, nigdy odwrotnie ${ }^{32}$. Pojęcia patriotyzmu również często było ukierunkowywane na naród jako jego punkt odniesienia. Naród był też najważniejszym elementem konstytuującym państwowość jako wartość samą w sobie. Dobrze ujął to bp Augustyn Łosiński: „głównym przedmiotem miłości ojczyzny, czyli patriotyzmu, bo to jest druga jej nazwa, jest miłość narodu, co też znajduje wyraz w potocznym języku, który pracę, na miłości ojczyzny oparta, nazywa w przeciwstawieniu do tendencji kosmopolitycznych, narodową"33. Pewnym paradoksem jest to, że zarówno stosunek polskiego Kościoła do narodu, jak i piłsudczyków do państwa, był pokłosiem zaborów - Polska mogła się odrodzić jako niezależny byt państwowy właśnie dzięki pielęgnowanym pieczołowicie wartościom narodowym i etosu państwowości I Rzeczypospolitej, w czym również Kościół katolicki miał wielkie zasługi i, rzecz jasna, zdawał sobie z tego sprawę.

Moralna ocena „państwa i narodu” oraz ich wzajemnych relacji, jak również nacjonalizm, były jednymi z gorących tematów podejmowanych

29 W.T. Kulesza, op. cit., s. 144-147.

30 K. Jakubiak, Kategoria państwa w kształtowaniu koncepcji wychowania państwowego w II Rzeczypospolitej, w: Wychowanie a polityka. Mity i stereotypy w polskiej myśli społecznej XX wieku, red. W. Wojdyła, Toruń 2000, s. 40.

31 P.A. Leszczyński, op. cit., s. 13.

32 T. Serwatka, Koncepcje, s. 58.

33 A. Łosiński, Chrześcijańska miłość ojczyzny i praca narodowa, Gniezno 1919, s. 2. 
wówczas przez katolickich intelektualistów. Do nacjonalizmu - pod warunkiem że nie wiązał się on z szowinizmem - przychylnie odnosił się wybitny i znany historyk Oskar Halecki, a znany i cieszący się autorytetem dominikanin o. Jacek Woroniecki opowiadał się za państwem jednolitym narodowo ${ }^{34}$. Nacjonalizm był wówczas pojęciem rozumianym nieco inaczej niż współcześnie, kiedy to po doświadczeniach II wojny światowej na ogół kojarzy się z czymś skrajnym, nieodłącznie z szowinizmem i zaakcentowaną niechęcią do innych narodów.

Oczywistą konsekwencją takiego stanu rzeczy było to, że przytłaczająca większość przedstawicieli polskiego kleru optowała za endecką opcją polityczna, nie była to jednak jedyna przyczyna proendeckich zapatrywań wielu polskich duchownych. Jak zaznacza Paweł Leszczyński, „decydujący wpływ na formułowanie poglądów biskupów na różne orientacje polityczne II Rzeczypospolitej wywarł czynny udział kleru w pracach obozu narodowego przed 1918 r., w tym głównego jego nurtu związanego z Ligą Narodową [...]. W młodości należało do niego organizacyjnie kilku biskupów" ${ }^{\prime 35}$. Stąd też sentyment, jakim przedstawiciele Episkopatu darzyli ruch narodowy.

\section{GŁÓWNI OPONENCI W EPISKOPACIE POLSKI}

Na czołowe miejsce wśród nich, jeśli chodzi o oponentów obozu piłsudczykowskiego, wysuwał się arcybiskup ormiański Józef Teodorowicz. „Dlaczego Teodorowicz wybrał właśnie środowisko narodowe jako sobie najbliższe? Bo bliski był mu kierunek ideowy tego obozu politycznego: patriotyzm połączony z wrażliwością na kwestie społeczne, akcentowanie konieczności awansu warstw ludowych, wreszcie wszechpolskość, czyli aktywność patriotyczna obejmująca wszystkie trzy zabory"36. Jak zauważa Krzysztof Krasowski, miał on niewiele stosunkowo obowiązków duszpasterskich, gdyż archidiecezję ormiańską pod względem wielkości co do liczby wiernych można przyrównać do przeciętnej parafii rzymskokatolickiej. Miał także w Episkopacie oponentów, którzy zarzucali mu podporządkowywanie interesu Kościoła sprawom partii ${ }^{37}$. Pomimo

34 Nacjonalizm a katolicyzm. Opinie biskupów, uczonych, polityków i publicystów wspótczesnych (tekst z roku 1927), tłum. J. Puzynianek, Krzeszowice 2007, s. 109-110.

35 P.A. Leszczyński, op. cit., s. 21-22.

36 J. Engelgard, Religia i polityka - Józef Teodorowicz i Narodowa Demokracja w latach 1902 1918, w: Teodorowicz. Mówca i patriota. Materiały z konferencji naukowej, red. T. Skoczek, Warszawa 2015, s. 119.

37 K. Krasowski, Między, s. 78. 
tego zdobył ogromny autorytet zarówno wśród wiernych, jak i w samym Episkopacie. Jak wskazuje Tadeusz Trajdos, „autorytet wyrobił sobie jednak nie kościelnym dostojeństwem, lecz wieloma manifestacjami odwagi moralnej i cywilnej, a także dzięki głębokiej erudycji i niezwykłemu darowi wymowy. [...] Uważano go za «nowego Piotra Skargę» w dobie walki o niepodległą Polskę" ${ }^{38}$. Choć Teodorowicz formalnie nie był członkiem SDN, to jednak „nigdy się od narodowej demokracji nie oddalił, tak w sensie politycznym, jak i ideowym"39. Jak nie trudno się domyślić, do spółki z abpem Adamem Stefanem Sapiehą był jednym z głównych kontestatorów rządów sanacyjnych w Polsce, zaś J. Piłsudskiego zwykł nazywać „demonem Polski” 40 . Zawzięcie zwalczał federacyjne plany Marszałka, współdziałając w tej kwestii z R. Dmowskim ${ }^{41}$. Zabrał głos w tej sprawie także w swoim słynnym kazaniu Sztandar narodowy z sierpnia 1920 r. Marzył o odzyskaniu województwa podolskiego, które J. Piłsudski obiecał Szymonowi Petlurze, krytykował także "granicę ryską" ${ }^{42}$. Zamach majowy jego zdaniem "oddał Polskę w ręce jednego, obłąkanego człowieka i klikę ludzi, z małymi wyjątkami pozbawionych wszelkiej znajomości rządzenia, przy zupełnym braku poczucia odpowiedzialności, a za to przy rządzy władzy, okupionej choćby kosztem Polaków"433. Biskup Teodorowicz był autorem memoriału, w którym ostro skrytykował J. Piłsudskiego, jednak pod wpływem kard. A. Hlonda biskupi zdecydowali, że nie przedstawią go Marszałkowi ${ }^{44}$. Ogółem do polityki prymasa bp Teodorowicz także odnosił się bardzo krytycznie, zwłaszcza do podejmowanych przez niego prób pojednawczych z władzami sanacyjnymi. To przede wszystkim dzięki postawie kard. A. Hlonda nie udało się Teodorowiczowi zjednoczyć Episkopatu Polski wokół kierowanego przez R. Dmowskiego Obozu Wielkiej Polski. Mimo wszystko utrzymywał on z prymasem życzliwe stosunki, próbując go wielokrotnie przekonywać do własnych racji, choć bez żadnych rezultatów ${ }^{45}$.

Szczególny posłuch idee propagowane przed endecję zyskały zwłaszcza w diecezji łomżyńskiej. Biskup łomżyński, Stanisław Łukomski,

38 T.M. Trajdos, Uwagi o działalności politycznej i przekonaniach arcybiskupa Józefa Teodorowicza, w: Teodorowicz. Mówca i patriota, red. T. Skoczek, Warszawa 2015, s. 68-69.

39 J. Engelgard, op. cit., s. 140-141.

40 R. Król-Mazur, Działalność polityczna abp. Józefa Teofila Teodorowicza w latach 1888-1923, Kraków 2013, s. 19.

41 Ibidem, s. 105.

42 T.M. Trajdos, op. cit., s. 83.

43 Cyt. za: K. Krasowski, Biskupi katoliccy II Rzeczypospolitej. Słownik biograficzny, Poznań 1996, s. 295.

44 R. Król-Mazur, op. cit., s. 19.

45 K. Krasowski, Biskupi, s. 295-296. 
popierał opcję narodowa, która jego zdaniem była bliska chrześcijańskim wartościom. W środowiskach rządowych odbierano to jako działalność wymierzoną przeciwko państwu polskiemu ${ }^{46}$. Ksiądz Wojciech Guzewicz, powołując się na ustalenia H. Majeckiego, stwierdza, że o popularności Narodowej Demokracji w kościele łomżyńskim zadecydowały czynniki takie jak „prokatolicki program i silnie rozbudowana sieć organizacyjna". Wojewoda białostocki w 1934 r. zgromadził dane, z których wyni$\mathrm{ka}$, że po stronie endecji opowiadali się „prawie wszyscy księża diecezji łomżyńskiej", a także biskupi Stanisław Łukomski i B. Dembek. Wielu kapłanów w diecezji łomżyńskiej organizowało też często specjalne nabożeństwa w intencji dalszego rozwoju Stronnictwa Narodowego ${ }^{47}$. Biskup Stanisław Łukomski wielokrotnie musiał stawać w obliczu nieuchronnego konfliktu z władzami państwowymi. Mimo iż na samym początku urzędowania w 1926 r. jego stosunki ze stroną rządową układały się raczej pomyślnie, począwszy od roku 1928 zaczęły się one stopniowo pogarszać. W zatargach z władzą państwową niewątpliwie prym wiodła diecezja łomżyńska. Świadczyć o tym może chociażby pismo nadesłane z Urzędu Wojewódzkiego w Białymstoku do MWRiOP, zatytułowane „Zestawienie materiałów o tych duchownych, których działalność jest niepożądana dla Państwa”. Na liście 17 kapłanów „nielojalnych” aż 15 wywodziło się z diecezji łomżyńskiej ${ }^{48}$. Biskup Łukomski wraz z podległym mu duchowieństwem opowiadał się za endecją widząc w niej ideę, która w założeniu najlepiej przystaje do katolickiej wizji państwa. Przedstawiciele władzy odbierali to jako ewidentny zamach na państwo i jego rząd co, jak słusznie zauważa ks. Tadeusz Białous, „zapewne nie było ani słuszne, ani obiektywne" 49 . Adwersarze zarzutów wysuwanych przez biskupa nie pozostawali mu dłużni: łomżyńskiemu biskupowi imputowano wywieranie złego wpływu na polskie społeczeństwo i działanie na szkodę państwa ${ }^{50}$. Już w 1932 r. wojewoda białostocki wystosował pismo do ministra Ministerstwa Wyznań Religijnych i Oświecenia Publicznego, w którym przedstawił zarzuty pod adresem biskupa Łukomskiego mające dowodzić tego, że wielokrotnie złamał on art. XIII konkordatu. Wśród 14 inwektyw, które omówiono na 24 stronach, znalazły się zarzuty m.in. o domniemane

\footnotetext{
46 T. Białous, Biskup Stanisław Kostka Łukomski (1874-1948). Pasterz niezłomny, Rajgród 2010, s. 151.

47 W. Guzewicz, Duchowieństwo diecezji łomżyńskiej w II Rzeczypospolitej, Lublin 2003, s. 219-220.

48 Uderzające jest zapisanie w tytule dokumentu terminu „państwo” z wielkiej litery. Zob. T. Białous, op. cit., s. 147.

49 T. Białous, op. cit., s. 151.

50 W. Guzewicz, Internowanie biskupa Stanisława Łukomskiego, czyli o obchodach żałobnych Marszałka Piłsudskiego w diecezji łomżyńskiej, „Studia Ełckie” 2014, 16, 3, s. 268.
} 
podburzanie młodzieży szkolnej do wystąpień antyżydowskich; wydany zakaz głoszenia kazań w święta państwowe niezwiązane bezpośrednio religią katolicką; wydanie listu z okazji obchodów uroczystości Chrystusa Króla 25 października 1931 r. broniącego katolickiego wychowania młodzieży i świętości węzła małżeńskiego, w którym rzekomo występował przeciwko działalności państwa; zwalczanie tak przez biskupa, jak i przez podlegających mu księży Związku Strzeleckiego i Zjednoczenia Związku Młodzieży Wiejskiej i Ludowej przy jednoczesnym popieraniu Stowarzyszenia Młodzieży Polskiej; czy wreszcie tworzenia negatywnego nastawienia kleru w diecezji do J. Piłsudskiego ${ }^{51}$.

Wielu innych biskupów spoglądało także na endeków przychylnym okiem. Przykładowo, poglądy polityczne abpa Bolesława Twardowskiego były zbliżone do tych, które prezentowała Narodowa Demokracja. Grzegorz Chajko uzasadnia to tym, że „wiązało się to zapewne z umiłowaniem ojczyzny i przekonaniem o słuszności tez głoszonych przez to ugrupowanie" $^{\prime \prime 2}$. Jak się wydaje, przyczyny, dla których Narodowa Demokracja cieszyła się tak wielką popularnością wśród kleru, mają różne podłoże, nie tylko ideologiczne. Pamiętać jednak należy o tym, że niektórzy biskupi nie byli oficjalnie zwolennikami endecji, jednak mimo wszystko obóz piłsudczykowski ostro krytykowali. Biskup Edmund Dalbor co prawda odnosił się z szacunkiem do J. Piłsudskiego jako głowy państwa, jednak jego stosunek do Marszałka można określić jako chłodny ${ }^{53}$. Odnoszenie się z rezerwą do J. Piłsudskiego było typowe dla całej Wielkopolski, m.in. ze względu na odmienny stosunek Wielkopolan do kwestii kształtu granic Rzeczypospolitej po zakończeniu wojny ${ }^{54}$.

Innym oponentem J. Piłsudskiego był arcybiskup krakowski Adam Stefan Sapieha. Przez cały niemal okres pasterzowania w Krakowie abp Sapieha przyjaźnił się z abpem Teodorowiczem ${ }^{55}$ i choć sam endekiem nigdy nie był, nie jest wykluczone, że ten ostatni wywierał na niego duży wpływ, także jeśli chodzi o zapatrywania polityczne. Już w czasie I wojny światowej sprzeciwiał się on zarówno Naczelnemu Komitetowi Narodowemu, jak i Legionom Polskim. Wespół ze wspomnianym biskupem ormiańskim Józefem Teodorowiczem apelował do władz austriackich o podjęcie interwencji przeciwko planowanemu powierzeniu biskupowi

\footnotetext{
51 T. Białous, op. cit., s. 150-151.

52 G. Chajko, Arcybiskup Bolestaw Twardowski (1864-1944). Metropolita Lwowski obrzadku tacińskiego, Rzeszów 2010, s. 357.

53 C. Pest, Kardynat Edmund Dalbor (1869-1926). Pierwszy Prymas Polski odrodzonej, Poznań 2004, s. 225.

54 Obóz piłsudczykowski optował za pozostawieniem kwestii zachodnich granic decyzjom Ententy. Zob. C. Pest, op. cit., s. 226.

55 R. Król-Mazur, op. cit., s. 16.
} 
Władysławowi Bandurskiemu stanowiska biskupa polowego Legionów ${ }^{56}$. Być może wynikało to z tradycji biskupów krakowskich, przywiązanych do konserwatywnej strony ugrupowań politycznych, optujących za koncepcją lojalistyczną. Wierny ideom krakowskiego konserwatyzmu w wydaniu stańczykowskim był już biskup krakowski Albin Dunajewski który, pomimo przypisywanej mu powstańczej legendy, nie był zaangażowany w powstanie styczniowe, czym narażał się na krytykę części duchowieństwa optującego za powstaniem narodowym; odmówił on także złożenia deklaracji o lojalności względem cara, wymawiając się poddaństwem wobec cesarza Franciszka ${ }^{57}$. Także poprzednik Sapiehy na stanowisku biskupa krakowskiego, kard. Jan Puzyna, był posądzany o związki ze stańczykami. Arcybiskupstwo krakowskie prosperowało w tym czasie bardzo dobrze dzięki koneksji z katolickim dworem habsburskim. Nic zatem dziwnego, że arcybiskup Sapieha przyjął takie, a nie inne stanowisko wobec obozu piłsudczykowskiego. Już po odzyskaniu przez Polskę niepodległości, w 1922 r. z ramienia Chrześcijańskiego Związku Jedności Narodowej, będącego koalicją endecji, chadecji i innych pomniejszych ugrupowań, piastował stanowisko senatora Rzeczypospolitej ${ }^{58}$. Jednakowoż pozostawał nieprzejednanym opozycjonistą rządu stronników Marszałka J. Piłsudskiego. Wielokrotnie protestował przeciwko istniejącej sytuacji społeczno-politycznej, będącej wynikiem rządów sanacji, zaś Konstytucja kwietniowa została jego zdaniem uchwalona nielegalnie ${ }^{59}$. Arcybiskup Sapieha pod wieloma względami popierał program endecji, choć najbliżej było mu do Stronnictwa Pracy - kontynuatora chadecji, z którym utrzymywał kontakty jeszcze po II wojnie światowej. Na negatywną ocenę piłsudczyków na pewno rzutowała jego pamięć o tzw. wydarzeniach krakowskich z 1923 r. Manifestacja na ulicy Dunajewskiego w Krakowie, zorganizowana przez PPS przeciwko „wyzyskowi i trudnej sytuacji robotników”, przekształciła się $\mathrm{w}$ krwawe starcie z wojskiem, przy czym jako pierwsi ogień otworzyli manifestanci. Stanowisko krakowskiego biskupa było jednoznaczne: „okryliśmy się wstydem i hańbą w oczach całej Polski" ${ }^{\prime 60}$. Manifestantom odmówił katolickiego pochówku, uzasadniając to tym, że "pogrzeb katolicki nie może być prowadzony pod czerwonym sztandarem". Stanowisko to wzbudziło wiele kontrowersji. Rozpowiadano najbardziej wymyślne,

56 „Godziemba”, Konflikt wawelski w 1937 roku, http://www.jpilsudski.org/artykuly-historyczne-pilsudski/epizody-z-zycia-jozefa-pilsudskiego/item/2025-konflikt-wawelski-w-1937-roku [dostęp: 4 V 2018].

57 M. Sadowski CSsR, Mit powstańczej legendy kard. Albina Dunajewskiego, „Analecta Cracoviensia" 2014, 46, s. 42.

58 Ibidem.

59 D. Macała, Polska katolicka w myśli politycznej II RP, Zielona Góra 2004, s. 314.

60 J. Czajowski, Kardynał Adam Stefan Sapieha, Wrocław 1997, s. 67. 
fałszywe kalumnie na temat krakowskiego duchowieństwa, wedle których księża mieli m.in. strzelać do tłumów, a na wieżach kościołów miały być poustawiane karabiny maszynowe ${ }^{61}$. Sapieha nie zgadzał się na budowę systemu autorytarnego przez obóz rządzący po 1926 r., zarzucając mu, że z państwa czyni „bożyszcze wszystko wchłaniające”. Wytykał mu podważanie autorytetu Kościoła w społeczeństwie, lekceważąco odnosił się także do polityków sanacyjnych ${ }^{62}$. Mimo wszystko opowiadał się za koniecznością współpracy z rządem, wskazując, że jest to nieodzowne tak dla dobra kraju, jak i samego Kościoła.

Spory J. Piłsudskiego z biskupami wyrażały czasem jego osobiste antypatie. Niewątpliwie największą awersją spośród wszystkich hierarchów Kościoła J. Piłsudski darzył bpa polowego Wojska Polskiego Stanisława Galla, który pod wpływem powziętych przez tego pierwszego kroków zrezygnował z piastowanej przez siebie funkcji. Marszałek wielokrotnie wysuwał żądania jego usunięcia, zwłaszcza po zamachu majowym. W rozmowie z ówczesnym nuncjuszem Francesco Marmaggim J. Piłsudski miał powiedzieć: „nazywam go świnią i to plugawą. Księdza Galla mogło to spotkać, że każdy oficer miałby prawo go bić po pysku i ja nie mógłbym wobec takiego faktu wyciągnąć konsekwencji; taki czyn byłby bezkarny [...]. Gall to nierób. Pełen intryg i świństw [...]. Nie mogłem go ani chwili trzymać w wojsku, lepiej zabić niż w wojsku trzymać w sprzeczności z honorem" ${ }^{\prime 63}$. Sytuacja była na tyle napięta, że bp Gall nie mógł uczestniczyć w otwarciu Domu Katolickiego w Łomży ze względu na zatarg z Marszałkiem. Zrobił to kilka dni później ${ }^{64}$. Papież Pius XI miał go odwołać ze względu na sympatię, jaką darzył J. Piłsudskiego ${ }^{65}$. Za sprawą A. Hlonda, który osobiście dokonał aktu konsekracji, jego następcą został ks. Józef Gawlina, dawny znajomy prymasa ${ }^{66}$. Biografista bpa Galla ks. Józef Panaś wskazuje, że przyczyną tego zatargu była krytyka zamachu majowego czyniona przez polskiego biskupa polowego, a także jego otwarte piętnowanie rozwiązłości oficerów wojskowych ${ }^{67}$ oraz ich

\section{Ibidem.}

62 Gdy w 1926 r. wyjeżdżał do Stolicy Piotrowej, miał powiedzieć do swoich współpracowników: „pamiętajcie dać mi znać do Rzymu, gdyby na moje miejsce zamierzano przysłać jakiegoś majora". Zob. J. Czajowski, op. cit., s. 70.

63 K. Krasowski, Biskupi, s. 68.

64 T. Białous, op. cit., s. 159, przyp. 629.

65 K. Krasowski, Biskupi, s. 68.

66 T. Serwatka, Koncepcje, s. 28. Biskup Gawlina utrzymywał dobre stosunki z marszałkiem; wcześniej pełnił funkcję informatora A. Hlonda, którą realizował przy użyciu korespondencji. Zob. K. Krasowski, Biskupi, s. 61.

67 Chodziło tutaj przede wszystkim o powszechne rozwody i życie w ponownym związku. 
przynależności do lóż masońskich ${ }^{68}$. Biskup Stanisław Gall, pomimo tych animozji, miał na swoim koncie ogromne zasługi, jeśli chodzi o utworzenie i organizację duszpasterstwa wojskowego ${ }^{69}$.

Wielokrotnie dochodziło do innych incydentów, których podłoża należy się doszukiwać w osobistej niechęci przedstawicieli polskiego episkopatu wobec J. Piłsudskiego. Miały one miejsce od samego początku istnienia II Rzeczypospolitej. Dla przykładu, gdy J. Piłsudski miał przyjąć stopień marszałka, aktu wręczenia buławy marszałkowskiej w belwederze miał dokonać prymas Polski bp. Edmund Dalbor. Ten jednak konsekwentnie udawał chorego, czemu przedstawiciele obozu rządowego dali wiarę - aktu dokonał ostatecznie kard. A. Kakowski ${ }^{70}$. W związku z tym, że niektórzy biskupi okazywali zbyt otwarcie niechęć wobec J. Piłsudskiego, na zjeździe Episkopatu Polski w 1921 r. opracowano specjalną procedurę przyjmowania Naczelnika Państwa w kościołach ${ }^{71}$.

\section{ECHA KONFLIKTU NA ŁAMACH PUBLICYSTYKI PRASOWEJ}

Konflikt Kościoła katolickiego z obozem piłsudczykowskim znalazł swój oddźwięk w prasie. W II Rzeczypospolitej prasa katolicka osiągała najwyższe nakłady; wśród niej największe sukcesy odnosił „Rycerz Niepokalanej”, którego nakład sięgał nawet 800 tysięcy egzemplarzy. Polscy hierarchowie kościelni chcieli skrupulatnie wdrażać nowoczesne metody ewangelizacji za pośrednictwem nowych mediów, aby jednocześnie uniezależnić się od jakichkolwiek wpływów z zewnątrz. Znamienne, że niedługo po zamachu majowym, bo już w 1927 r., zaczęła funkcjonować Katolicka Agencja Prasowa, a w rok później Komisja Prasowa Konferencji Episkopatu ${ }^{72}$. Andrzej Paczkowski uważa, że przyczyną tego stanu rzeczy była chęć uniezależnienia się Kościoła od prawicowych i centroprawicowych stronnictw politycznych, z których większość opowiadała się za współpracą z klerem. Prasa katolicka była z reguły apolityczna, choć jak podkreśla Władysław Kolasa, jeśli chodzi o kwestie ideologiczne

\footnotetext{
68 J. Prochwicz, Arcybiskup Stanisław Gall (1865-1942). Biskup Polowy Wojsk Polskich, Warszawa 2018, s. 40.

69 Przypomniano o tym 14 marca 2018 r. w rocznicę utworzenia biskupstwa polowego, kiedy to szczątki bpa Galla przeniesiono do krypty w katedrze polowej i odprawiono ponowny pogrzeb. W uroczystościach brało udział wielu biskupów, w tym przewodniczący Konferencji Episkopatu Polski oraz prezydent RP Andrzej Duda.

70 C. Pest, op. cit., s. 226-227.

71 Ibidem, s. 226, przyp. 394.

72 W.M. Kolasa, Kierunki badań nad historia prasy polskiej 1918-1939, cz. 1, Tendencje rozwojowe, typologia, „Rocznik Historii Prasy Polskiej” 2011, 14, 1-2 (27-28), s. 48.
} 
skłaniała się wyraźnie ku rozwiązaniom proponowanym przez chadecję i endecję. Trudno się temu dziwić, gdyż po zamachu majowym to właśnie chadecja wspólnie z endecją prezentowały postulaty zbieżne z tymi sugerowanymi przez katolicką naukę społeczną, stroniąc od socjalizmu i rozwiązań antyklerykalnych, które pojawiały się w przypadku prasy sprzyjającej piłsudczykom. Można więc uznać, że ideologiczne analogie postulatów prasy katolickiej oraz tej z prawicowych nurtów politycznych były raczej kwestią przypadku aniżeli pokłosiem zamierzonych działań, zmierzających do poparcia konkretnej formacji politycznej. Kościół nie był jednak reprezentowany w silny sposób przez prasę codzienną uzależnioną od siebie, choć starał się utrzymywać związki z periodykami odwołującymi się do katolickiej nauki, czego wyrazem były dla przykładu zjazdy pisarzy katolickich, odbywające się pod egidą najwyższych dostojników kościelnych ${ }^{73}$.

Pewien ewenement stanowiło jednak czasopismo "Pro Christo", wydawane w Warszawie przez Zgromadzenie Księży Marianów, jawnie krytykujące obóz rządowy. Władzy zarzucano, że stosuje metody konspiracyjne i rewolucyjne, wyniesione $z$ dawnego socjalistycznego podziemia, rozbudowę aparatu inwigilacji społeczeństwa, występowanie przeciwko religii katolickiej poprzez m.in. notoryczną konfiskatę prasy katolickiej, metody „rozprawiania się" z oponentami politycznymi typowymi dla rozwiązań totalitarnych, krytykowano także myśl polityczną piłsudczyków i ich sprzyjanie członkom wolnomularstwa w realizacji kariery politycznej, jak również ich ideę supremacji państwa nad narodem ${ }^{74}$.

Z kolei przykładem pisma mającego poniekąd przychylne nastawienie do sanacyjnej ekipy rządzącej może być „Kurier Łódzki”, mający charakter katolicko-narodowy, który poparł zamach majowy i nowo tworzony obóz sanacyjny, choć na jego łamach pojawiały się także akcenty krytykujące poczynania rządu. Jego stosunek do ekipy rządzącej Andrzej Paczkowski określił mianem „przychylnej neutralności”. Choć pismo pod koniec lat trzydziestych wiązano z Obozem Zjednoczenia Narodowego, w dalszym ciągu można było uznać, że jest ponadpartyjne i ograniczające się w swoich wypowiedziach do przedstawiania nauki Kościoła, unikając jednocześnie wypowiedzi na temat bieżącej polityki wewnętrznej państwa ${ }^{75}$. „Głos Prawdy", polskie czasopismo społeczno-polityczne o orientacji

\footnotetext{
73 A. Paczkowski, Prasa w życiu politycznym Drugiej Rzeczypospolitej, „Dzieje Najnowsze" 1978, 10, 3, s. 46.

74 A. Danek, Wspótpraca miesięcznika „Pro Christo” ze środowiskiem Bolesława Piaseckiego jako wynik "planu penetracyjnego" Falangi, w: Nacjonalizmy różnych narodów. Perspektywa politologiczno-religioznawcza, red. B. Grott, O. Grott, Kraków 2012, s. 135-139.

75 M. Hrycek, Wątki antysemickie w "Kurierze Łódzkim” w okresie międzywojennym, „Folia Litteraria Polonica" 2012, 17, 3, s. 19 i n.
} 
zdecydowanie propiłsudczykowskiej, zarówno przed, jak i po zamachu majowym publikowało antyklerykalne treści, w których domagano się wyrugowania Kościoła katolickiego z polskiej polityki, likwidacji korzystnego dlań prawa, nie wyłączając konkordatu ${ }^{76}$. Postulaty te poniekąd interferowały z tymi, które były wysuwane przez najbardziej zajadłych przedstawicieli lewicy, takich jak działacz ruchu ludowego Józef Putek (1892-1974), u którego walka o rewizję konkordatu urosła wręcz do rangi obsesji ${ }^{77}$. Piłsudczykowska "Gazeta Polska", choć przekazywała także obiektywne informacje z życia Kościoła, publikując m.in. wszystkie wystąpienia prymasa A. Hlonda, to jednak wielokrotnie krytykowała Kościół. Częstokroć można było w niej natrafić na sensacyjne doniesienia związane z amoralnym prowadzeniem się poszczególnych duchownych. Kościół był na łamach niniejszego czasopisma krytykowany także ze względu na sprzeciw wobec kultu Marszałka, prowadzenie agitacji politycznej, a także prerogatywy związane z wychowaniem młodzieży. Trudno zatem zgodzić się z tezą Jerzego Seniówa, jakoby „stosunek piłsudczyków i »Gazety Polskiej« do Kościoła katolickiego wynikał w zasadzie z ustaleń konkordatu między Polską a Stolicą Apostolską z roku 1925"78.

\section{KOŚCIÓŁ WOBEC RZĄDÓW SANACJI}

W okresie przypadającym na czasy bezpośrednio przed zamachem majowym można było wyczuć coraz bardziej napiętą sytuację społeczno-polityczną, także w środowiskach katolickich. Mnożyły się w tym czasie akcenty bliskie teoriom spiskowym. Niektórzy duchowni byli wprost przekonani o tym, że w Polsce szykuje się prawdziwy przewrót. Jednym z nich był ksiądz Józef Prądzyński, który w artykule na łamach „Wiadomości dla Duchowieństwa” wyrażał swoje obawy o zbliżającym się nieuchronnie przewrocie politycznym i religijnym, w którym główną rolę odegrają jego zdaniem Żydzi, a w dalszej kolejności masoneria. Polskie duchowieństwo zdaniem ks. Prądzyńskiego powinno być w związku z tym odpowiednio skonsolidowane, aby móc stawić czoła tak pojętemu wrogowi ${ }^{79}$. Złowróżbny klimat, który panował w społeczeństwie polskim

76 W.T. Kulesza, op. cit., s. 86.

77 Zob. A. Synowiec, W kręgu publicystyki Józefa Putka - spór z Kościołem katolickim, „Studia Historyczne" 2014, 57, 2, s. 225-242.

78 J. Seniów, W kręgu piłsudczyków. Poglady ideowo-polityczne "Gazety Polskiej" (19291939), Kraków 1998, s. 128-133.

79 D. Pałka, Warunki dialogu Kościoła katolickiego z Żydami w II Rzeczypospolitej, „Poznańskie Studia Teologiczne" 2005, 18, s. 152-153. 
w związku z kryzysem politycznym z połowy lat dwudziestych, udzielał się zatem także duchowieństwu katolickiemu.

Do zamachu stanu w 1926 r. rzeczywiście doszło i polscy hierarchowie kościelni stanęli przed faktem dokonanym. Biskupi pomocniczy archidiecezji gnieźnieńskiej i poznańskiej: A. Laubitz i S. Łukomski w liście do wiernych z 14 maja 1926 r. pisali: „wieść straszna wstrząsnęła krajem polskim. Kilku dowódców wojskowych powstało przeciwko prawowitej władzy państwowej i wszczęło bratobójcze walki w stolicy Polski w Warszawie, wciągając w nie niewinnych żołnierzy i ludność cywilną. A stało się to $\mathrm{w}$ chwili, w której nowy rząd zabierał się skutecznie do pracy około tworzenia zdrowszych i pomyślniejszych warunków w kraju. W ciężkim tym doświadczeniu wzywamy was do gorącej modlitwy, iżby się Bóg ulitować raczył nad znękaną Ojczyzną i sprawił, aby wojna ta domowa jak najprędzej opanowana została. W tym celu zarządzamy dodawanie przy nabożeństwie majowym suplikacji. Poza tym prosimy i napominamy, abyście zupełny zachowali spokój i rozwagę, oddając się nadal swoim obowiązkom sumiennie oraz dając chętny i karny posłuch władzom prawowitym. Tak postępując, złagodzicie straty i rany, jakie ponoszą kraj i naród". Choć większość biskupów oraz księży w stosunku do zamachu majowego zajęła dość zachowawcze stanowisko, znaleźli się też tacy, którzy wyrazili swój zdecydowany sprzeciw, a byli wśród nich abp A. Sapieha, abp J. Teodorowicz i bp. H. Przeździecki. Niechęć do J. Piłsudskiego wynikała także stąd, że jego obóz pod względem programowym wykazywał wówczas ewidentne tendencje antyklerykalne i po raz kolejny pojawiły się podejrzenia o jego silne związki z masonerią ${ }^{80}$. Kapelan Główny Legionów ks. Józef Panaś, 17 maja 1926 r. w kościele garnizonowym w Warszawie, odprawił nabożeństwo za poległych w warszawskich walkach żołnierzy, po czym zerwawszy wszystkie ordery, włącznie z Krzyżem Virtuti Militari, rzucił je pod nogi gen. Gustawowi Dreszerowi ${ }^{81}$. Arcybiskup Adam Sapieha uważał zamach majowy za złamanie konstytucji i cios w demokrację. Spotkał się z J. Piłsudskim dwukrotnie w 1927 r. Zasugerował wówczas, aby Marszałek skonsultował się z osobami o innych poglądach politycznych niż jego własne ${ }^{82}$. Pojawiały się jednak z rzadka także inne głosy. Kardynał A. Kakowski, już po zamachu majowym, w przemówieniu do duchowieństwa i wiernych

\footnotetext{
80 Cyt. za: J. Dębiński, Kościół rzymskokatolicki wobec przewrotu majowego i rządów sanacji, w: Zamach stanu Józefa Piłsudskiego i jego konsekwencje w interpretacjach polskiej myśli politycznej XX wieku, red. Z. Karpus, G. Radomski, W. Wojdyła, Toruń 2008, s. 220-221.

81 J. Dębiński, Józef, s. 116.

82 M. Rożek, Kardynał Sapieha, Kraków 2007, s. 70. Do tego typu spotkań faktycznie miało dochodzić.
} 
z okazji wyboru Ignacego Mościckiego na prezydenta Polski powiedział: „zaklinam was na Boga i dobro drogiej nam wszystkim ojczyzny, zachowajcie spokój o godność obywatelska, niechaj nikt nie ośmiela się zakłócić porządku i ładu"83. Choć J. Piłsudski propozycję dyktatury odrzucił" ${ }^{84}$, to badacze dostrzegają skrajne tendencje w sytuacji politycznej w Polsce po zamachu majowym ${ }^{85}$.

Rządy sanacyjne wcale jednak nie oznaczały ocieplenia stosunków obozu piłsudczykowskiego $\mathrm{w}$ z klerem, wręcz przeciwnie. $\mathrm{W}$ tzw. sprawie brzeskiej, gdy J. Piłsudski nakazał areszt kilkuset osób, w tym oponentów politycznych, stanowisko arcybiskupa Sapiehy nie budziło żadnych wątpliwości. W liście skierowanym do kard. A. Hlonda pisał: „stoimy przed jasnym faktem zupełnie bolszewickiego postępowania czynników rządowych" ${ }^{\prime 86}$. Sam kard. A. Hlond 9 października 1930 r. wysłał list do prezydenta dotyczący internowanych osób; został on także przedstawiony samemu J. Piłsudskiemu, jednak nie doczekano się odpowiedzi adwersarza. Prymas jeszcze wielokrotnie interweniował $u$ prezydenta, domagając się amnestii więźniów politycznych ${ }^{87}$. Mimo wszystko A. Hlond, nawet pod silnymi naciskami abpa Sapiehy, nie zdecydował się na zabranie oficjalnego głosu $\mathrm{w}$ „sprawie brzeskiej”"88.

Kościół katolicki nie zajął oficjalnie stanowiska w sprawie wspomnianej akcji wymierzonej w demokrację w 1930 r., co doprowadziło do powstania licznych krytycznych komentarzy pod jego adresem ${ }^{89}$. Nie znaczy to jednak, że sprawą tą biskupi w ogóle się nie zajmowali. 30 września 1930 r. w Warszawie Episkopat podjął temat „sprawy brzeskiej" na konferencji plenarnej, jednak ostatecznie nie podjęto żadnej wiążącej decyzji. Stanowiska nie chcieli zajmować kard. A. Kakowski i kard. A. Hlond, inną z kolei postawę przyjęli biskupi: A. Sapieha, J. Teodorowicz, B. Twardowski, H. Przeździecki i S. Łukomski. Nie wiadomo, co legło $u$ podstaw braku przyjęcia oficjalnego stanowiska w sprawie jawnej działalności totalitarnej ze strony władzy sanacyjnej w Polsce. Być może biskupi obawiali się represji wobec Kościoła. Sprawa była dla nich o tyle nagląca, że zawierała negatywny wydźwięk na

83 Cyt. za: M.M. Grzybowski, Kardynał II Rzeczypospolitej Aleksander Kakowski 1862-1938, „Notatki Płockie” 2013, 58, 1 (234), s. 18.

84 M. Rożek, op. cit., s. 15.

85 Zob. K. Kawalec, Przewrót majowy jako etap narastania w polskim życiu politycznym tendencji skrajnych, „Studia nad Autorytaryzmem i Totalitaryzmem” 2011, 33, s. 209-226.

86 Ibidem, s. 71.

87 J. Dębiński, Kościót, s. 227.

88 T. Serwatka, Kazimierz Świtalski (1886-1962). Biografia polityczna, Warszawa 2009, s. 124 .

89 G. Chajko, op. cit., s. 359. 
polu religijnym, jeśli chodzi o traktowanie więźniów politycznych. Może o tym świadczyć fakt, że Żydowi H. Liebermannowi, który miał zamiar dokonać konwersji na katolicyzm, odmówiono przed śmiercią wizyty księdza. Podobnie postąpiono z Wojciechem Korfantym ${ }^{90}$.

Zamach na demokrację i wydarzenia z 1930 r. nadwątliły pozycję J. Piłsudskiego, który wycofał się z życia politycznego ${ }^{91}$. Niemniej z okazji wyborów w 1930 r. biskupi nie wydali oficjalnej odezwy do wiernych. Obawiali się repliki ze strony władzy sanacyjnej, która interweniowała w Stolicy Apostolskiej celem potępienia Narodowej Demokracji w Polsce na wzór Action Française ${ }^{22}$. Niejasne pod względem światopoglądowym było także "prawe skrzydło" obozu piłsudczykowskiego. Przed wyborami w 1930 r. podnosili, że wprawdzie w skład bloku rządowego wchodzą także konserwatyści, jednakże jego stanowisko wobec religii jest nie do końca jasne, tym bardziej że niektórzy jego przedstawiciele budzili wątpliwości w środowiskach katolickich, jeśli chodzi o wysuwane przez nich postulaty ${ }^{93}$.

Gdy na początku lat trzydziestych sytuacja na linii państwo-Kościół w Polsce wyraźnie się zaostrzyła, do Rzymu został wezwany kard. A. Hlond, gdzie 16 marca 1932 r. złożył memoriał o sytuacji Kościoła w Polsce w kontekście bieżącej polityki państwa. „Charakteryzując władze państwowe, Prymas zwrócił uwagę na indyferentyzm religijny i negatywne nastawienie do katolicyzmu większości w bloku rządzącym w sejmie i senacie, a więc: socjalistów, wolnomyślicieli, sekciarzy, apostatów i masonów. Rząd, zdaniem kard. A. Hlonda, składał się przeważnie z legionistów o niezbyt wysokiej kulturze intelektualnej i o słabym przygotowaniu politycznym. W programie rządu nie została skrystalizowana idea państwa, która oscylowała między koncepcją faszystowską a koncepcją bolszewicką. Główną zasadą systemu politycznego była omnipotencja państwa. W szkole rozwijano kult Józefa Piłsudskiego". Prymas zwracał uwagę na kontrolę korespondencji duchowieństwa, zakładanie kartotek dla księży, w których odnotowywano ich poglądy polityczne; inwigilowano działaczy Akcji Katolickiej, bractwa, trzecie zakony i sodalicje mariańskie. $Z$ ważnych stanowisk rządowych byli usuwani praktykujący katolicy, a w ich miejsce trafiali ateiści, bigamiści i apostaci. Pięćdziesiąt osiem procent duchowieństwa nie miało zaufania do rządu, redukowano lekcje religii, praktykujących nauczycieli zastępowano niereligijnymi ${ }^{94}$.

\footnotetext{
90 J. Dębiński, Józef, s. 116-117.

91 W. Roszkowski, Najnowsze historia Polski 1914-1945, Warszawa 2003, s. 265-268.

92 J. Dębiński, Józef, s. 118.

93 J. Korzonkiewicz, Wobec polityki i wyborów, „Przegląd Katolicki” 1930, 36, s. 569.

94 J. Dębiński, Kościót, s. 230.
} 
Episkopat zmuszony był interweniować także w innych kwestiach, jak w przypadku znowelizowanego Kodeksu karnego, który dopuszczał aborcję w pewnych przypadkach ${ }^{95}$. Krytykowano też Komisję Kodyfikacyjną za to, że pragnie prawo małżeńskie ustalić w duchu liberalnym, bez wcześniejszej konsultacji z Kościołem ${ }^{96}$. Komisja Kodyfikacyjna nosiła się z zamiarem wprowadzenia ślubów cywilnych i usankcjonowania rozwodów. Możliwe wejście w życie tych dezyderatów określano mianem "policzka dla katolików”, którzy uznają nierozerwalność małżeńską, zaś rozwód - obojętnie czy udzielony przez władzę świecką, czy też jakąkolwiek wyznaniową - jest nieważny, a małżeństwo nie ustaje aż do śmierci któregoś z małżonków ${ }^{97}$. Zdając relację z rządowej dyskusji o prawie małżeńskim, pod datą 1 marca 1931 r. w Polsce Bronisław Żongołłowicz, wiceminister wyznań religijnych i oświecenia publicznego, w swoich dziennikach zapisał, powołując się na wywiady, jakie przeprowadził Aleksander Połczyński: „Piłsudski religijny, nawet zabobonny. Religijny Prezydent, sam Połczyńskiemu oświadczył, że jest wierzącym. Również Sławek. W ogóle bezbożników nie ma, są liberałowie. Ale Piłsudski oraz inni nie są klerykałami. Kościół katolicki nie jest w Polsce zorganizowany. Piłsudski mówił Połczyńskiemu: biskupów nie ma, to są plebani, nie mam z kim z nich rozmawiać. Liczyłem na Hlonda, lecz i ten swą umysłowością, poziomem zawiódł. Marmagii do niczego. [...] Mówiliśmy o niezorganizowanym katolicyzmie w Polsce, o parochach biskupach, o niedołężnym Nuncjuszu" ${ }^{\prime 98}$. Dyskusje na temat słabości Kościoła w Polsce i jego zaangażowania w życie polityczne toczyły się jak widać także w kręgach duchownych i przejawiały się dosyć ostrą krytyką.

Jeśli chodzi o konstytucję z 1935 r. na łamach prasy katolickiej w sposób szczególny zwracano uwagę na artykuły z poprzedniej konstytucji, tj. 99, 109, 118 i 129, które dotyczyły prawa własności, wolności sumienia i uprzywilejowanej pozycji Kościoła. Niniejsze kwestie zostały wyłożone w pełnym brzmieniu w nowej konstytucji, jednak ich przyszłość pozostawała pod znakiem zapytania z uwagi na to, że istniała możliwość dojścia do władzy prezydenta o antykościelnym nastawieniu, który mógłby

95 Ibidem, s. 228-230. Tematyka ta bywała też chętnie podejmowana na łamach prasy katolickiej, gdzie broniono życia poczętego. Zob. np. Z. Kozubski, Czy istnieja wskazania lekarskie na spędzenie płodu?, „Przegląd Katolicki” 1930, 7, s. 103-105.

96 Nowy kodeks a małżeństwo, „Przegląd Katolicki” 1930, 8, s. 127.

97 S. Podoleński, W sprawie kodyfikacji prawa małżeńskiego w Polsce, „Przegląd Powszechny" 1926, 169, 505, s. 152. Autor odniósł się w tej kwestii do przypadku podejmowanych często zmian wyznań przez katolików na protestanckie lub prawosławne celem uzyskania i uprawomocnienia rozwodu.

98 B. Żongołłowicz, Dzienniki 1930-1936, oprac. D. Zamojska, Warszawa 2004, s. 141142. 
przeforsować zmiany w konstytucji mające antyklerykalny charakter ${ }^{99}$. Z nowej konstytucji zniknęła inwokacja do Boga, co nie godzi się dla ustawy zasadniczej uchwalonej w kraju, w którym większość obywateli to katolicy. Konstytucyjna wzmianka o tym, że prezydent jest odpowiedzialny jedynie przed Bogiem i historia, zdawała się sugerować, że to państwo ma teraz w dużym stopniu zająć miejsce Boga ${ }^{100}$.

Państwo starało się także kontrolować na różne sposoby homilie księży, ruchy i stowarzyszenia diecezjalne, wysuwano także postulaty zmian na stanowiskach duchownych w poszczególnych parafiach ${ }^{101}$. „Odpowiednie instytucje państwowe kontrolowały również przebieg wydarzeń w Kościele katolickim. Wiedziały o wszelkich zmianach w hierarchii kościelnej, powstawaniu nowych parafii, przebiegu wizytacji biskupich, treści homilii, z których zdawały relacje do władz wyższego rzędu. [...] Ważną informacją dla MWRiOP w Warszawie była nawet liczba księży przyjmujących święcenia w poszczególnych diecezjach"102.

Istotny problem stanowiła inwigilacja duchownych przez rząd. W aktach można natrafić na wykaz duchownych, których władze podejrzewały o „działalność antypaństwową". Na pierwszym miejscu znajduje się w nim nazwisko ks. bpa Stanisława Łukomskiego. Łącznie lista obejmuje 113 księży i 3 biskupów ${ }^{103}$. Raport sytuacyjny dotyczący województwa nowogrodzkiego podnosił, że „kler katolicki pracując w różnych organizacjach katolickich, których na terenie województwa obecnie jest ponad 250, nie zawsze prowadzi pracę ustaloną statutem, lecz wykorzystując autorytet wśród ludności, często zwalcza organizacje prorządowe, wprowadzając rozdźwięk w społeczeństwie i przyczynia się do kształtowania idei narodowych wśród młodzieży"104. W 1932 r. wojewoda białostocki przesłał do ministra Ministerstwa Wyznań Religijnych i Oświecenia Publicznego w Warszawie pismo zawierające 14 zarzutów, wedle których bp Łukomski działał niezgodnie z konkordatem. Zarzucano mu m.in. to, że 10 października 1930 r. wydał orędzie do diecezjan w sprawie wyborów, w którym pod karą grzechu ciężkiego zakazywał głosować na ugrupowania politycznie wrogie Kościołowi, zwalczanie przez biskupa i proboszczów z jego diecezji takich

\footnotetext{
99 J. Rawicz, Konstytucja 1935 r., „Przegląd Katolicki” 1935, 13, s. 196.

100 A. Buczko, Nowa Konstytucja Rzeczypospolitej, „Przegląd Katolicki” 1935, 21, s. 246 247.

101 S. Bylina, Relacje państwo-Kościót katolicki na południowym Podlasiu w II Rzeczypospolitej, Drohiczyn 2013, s. 148-149.

102 Ibidem, s. 145.

103 J. Szymański, Stosunek Watykanu do spraw polskich za czasów II Rzeczypospolitej 19191939, Radom 1982, s. 164.

104 Cyt. za: W. Śleszyński, op. cit., s. 26.
} 
organizacji jak Związek Strzelecki, Zjednoczenie Związku Młodzieży Polskiej i Ludowej, przy jednoczesnym wspieraniu Stowarzyszenia Młodzieży Polskiej ${ }^{105}$.

\section{STOLICA APOSTOLSKA WOBEC SYTUACJI POLITYCZNEJ W POLSCE}

Aprobatywna postawa Stolicy Apostolskiej wobec rządów piłsudczykowskich w Polsce na pewno była czynnikiem, który hamował antagonistyczne nastawienie biskupów o orientacji opozycyjnej względem rządu. Pius XI, a właśc. Achilles Ratti, przed wyborem na Biskupa Rzymu, u progu odzyskania przez Polskę niepodległości pełnił funkcję nuncjusza apostolskiego w II Rzeczypospolitej i tak jak niektórym politykom europejskim - nie wyłączając z tego grona Hitlera - postać J. Piłsudskiego mogła mu imponować ${ }^{106}$, dla Polski widział zaś specjalne miejsce w dziejach świata i chrześcijaństwa. A. Ratti był także świadkiem ataku bolszewików na Polskę; nie opuścił Warszawy mimo grożącego mu niebezpieczeństwa. Marszałek zyskał wówczas jego zaufanie jako ten, który doprowadził do katastrofy bolszewicką inwazję i jej „marsz na Paryż". Jak stwierdza Jarosław Pietrzak, rolę nuncjusza A. Rattiego w belwederze można określić mianem persona gratissima. J. Piłsudski bardzo chętnie zasięgał porad nuncjusza i zawsze liczył się z jego zdaniem ${ }^{107}$. W styczniu $1919 \mathrm{r}$. A. Ratti przesłał list do premiera Ignacego Paderewskiego, w którym napisał: „Ojciec św., ze szczególną radością i dziękując Bogu za cudowne dzieło Jego Wszechmocy, sprawiedliwości i dobroci. Uznaje i pozdrawia Polskę, która zmartwychwstała, wstępuje do zespołu mocarstw, aby zajać miejsce, gdzie w ciągu wieków tak chlubnie położyła zasługi wobec cywilizacji i Kościoła..."108. Już jako papież był skłonny nazwać polskich biskupów "głupcami" i nakazywał ostro nuncjuszowi apostolskiemu w Polsce, aby „Episkopat nie szedł po linii antyrządowej”109. Zapewne Marszałek zdawał sobie sprawę z tego, jak ogromny wpływ na opinię publiczną wywiera Kościół katolicki i wolał go mieć po swojej stronie. Niewątpliwie doceniał też sentyment, jakim A. Ratti darzył Polskę, kraj bądź co bądź katolicki, który dopiero co odrodził się z niewoli. Trudno

\footnotetext{
105 T. Białous, op. cit., s. 150-151.

106 Dowodem na to może być portret marszałka Piłsudskiego, który w swoich apartamentach przechowywał papież.

107 J. Pietrzak, Nuncjatura Achillesa Ratti w Polsce w latach 1918-1921 w świetle wspomnień o niej, w: Vade Nobiscum, red. Z. Brzozowska et al., Łódź 2009, s. 264.

108 Cyt. za: J. Szymański, op. cit., s. 25.

109 B. Żongołłowicz, op. cit., s. 36-37.
} 
w tych ciepłych stosunkach doszukiwać się konkretnych katolickich inklinacji ze strony J. Piłsudskiego, gdyż relacje z nuncjuszem ograniczał wyłącznie do sfery politycznej, skupiając się na interesach reprezentowanego przez siebie kraju.

W czasie wojny polsko-bolszewickiej Stolica Apostolska wspierała moralnie Polaków ${ }^{110}$. Nie jest wykluczone, że to właśnie nuncjusz Watykanu w Polsce był twórcą koncepcji „cudu nad Wisłą”, którą rozpowszechniała w późniejszym czasie prasa Narodowej Demokracji ${ }^{111}$. Tym, co zbliżało A. Rattiego i J. Piłsudskiego, była właśnie nienawiść do komunizmu i Związku Sowieckiego, jak również niechęć do demokracji parlamentarnej i liberalizmu ${ }^{112}$. Jak stwierdza J. Szymański, „polityka papieska w stosunku do Polski była wypadkową stosunku Niemiec i Włoch z jednej oraz ZSRR z drugiej strony. Polska była dla Watykanu masa przetargowa w stosunku do głównego zadania kościoła podczas pontyfikatu Piusa XI, a mianowicie walki z komunizmem"113. Zdaniem tego samego autora Watykan aprobował rządy sanacyjne w Polsce przede wszystkim dlatego, że A. Ratti znał jeszcze z czasów nuncjatury $\mathrm{w}$ Polsce antykomunistyczne nastawienie J. Piłsudskiego, a rząd sanacyjny realizował postanowienia konkordatu z 1925 r. ${ }^{114}$ Co do tego ostatniego można mieć poważne wątpliwości; w drugiej połowie lat dwudziestych wielokrotnie wyrażali je zresztą polscy biskupi ${ }^{115}$. Sam J. Piłsudski już po zamachu majowym zlecił przekazać papieżowi wiadomość, że będzie blokował wszelkie zakusy do wprowadzenia w Polsce jakichkolwiek ustaw o charakterze antyreligijnym ${ }^{116}$. Jednakowoż Stolica Apostolska starała się nie wpływać destabilizująco na sytuację w II Rzeczypospolitej. Wyrazem tego było powierzenie przez Ojca Świętego arcybiskupstwa gnieźnieńskiego wcześniejszemu biskupowi katowickiemu A. Hlondowi, który nie był związany z żadną formacją polityczną ze względu na swój częsty pobyt za granicą ${ }^{117}$. Przychylny

\footnotetext{
110 S. Bylina, op. cit., s. 4.

111 J. Pietrzak, op. cit., s. 266.

112 J. Jurkiewicz, Watykan a Polska w okresie międzywojennym 1919-1939, Warszawa 1960,
} s. 79.

113 J. Szymański, op. cit., s. 176

114 Ibidem, s. 164.

115 J. Pietrzak, Czy kard. August Hlond był zwolennikiem sanacji?, w: Kościót w II Rzeczypospolitej, red. Z. Zieliński, S. Wilk, Lublin 1980, s. 87.

116 Kardynał A. Kakowski przed tym wydarzeniem po powrocie z Rzymu przesłał błogosławieństwo od papieża dla marszałka J. Piłsudskiego i narodu polskiego. Zob. J. Dębiński, Kościót, s. 221.

117 W.T. Kulesza, op. cit., s. 87. 
stosunek papieża do J. Piłsudskiego był czymś powszechnie wiadomym; wiedzieli o nim dyplomaci w całej ówczesnej Europie ${ }^{118}$.

Po zamachu majowym, wbrew oczekiwaniu wielu członków polskiego duchowieństwa, nie doszło do widocznej zmiany stosunków na linii Stolica Apostolska - obóz piłsudczykowski w Polsce. 26 maja warszawski „Nasz Przegląd” donosił: „,w dniu wczorajszym premier Bartel odwiedził kard. A. Kakowskiego, który powrócił z Rzymu. Wizyta trwała blisko godzinę. Dowiadujemy się, że kardynał A. Kakowski przywiózł błogosławieństwo papieskie dla marszałka Piłsudskiego i dla rządu p. Bartla"119. J. Piłsudski brał udział w uroczystościach związanych z koronacją obrazu Madonny Ostrobramskiej 2 sierpnia 1927 r. Wówczas miał powiedzieć ciepłe słowa o papieżu Piusie XI następującej treści: „złączeni jesteśmy z Jego Świętobliwością pierwszymi poczynaniami życia państwowego. Gdy Jego Świętobliwość był nuncjuszem jako Achilles Ratti, z jego przeżyć ówczesnych wspólnych nie mogliśmy nie wnieść głębokiego przekonania, że możemy być zawsze pewni jego uczuć i sentymentu do nas. Chcę zaznaczyć, że Polska nie tylko ma serdecznego przyjaciela, ale i że sercem umie to być ukazanym [...]"120. Zaufanie, jakim papież darzył J. Piłsudskiego, bywało czasem problematyczne dla polskiego Episkopatu, z którym w tej sprawie nie zawsze się liczono w Watykanie ${ }^{121}$.

\section{POSTAWA KARD. ALEKSANDRA KAKOWSKIEGO \\ I KARD. AUGUSTA HLONDA}

Wśród polskich hierarchów katolickich, którzy optowali za współpracą z władzami sanacyjnymi, na pierwszy plan wysuwają się w zasadzie dwie najważniejsze postacie polskiego Kościoła w tamtych czasach, a mianowicie: kard. A. Kakowski i kard. A. Hlond ${ }^{122}$. Z reguły starali się oni iść po linii, jaka została wytyczona przez Piusa XI. Kardynał A. Kakowski 14 listopada 1918 r. wystosował pismo do J. Piłsudskiego w imieniu Rady Regencyjnej, której był członkiem, w którym zawarta była sentencja o jej rozwiązaniu i przekazaniu władzy adwersarzowi. Oficjalny i podniosły ton wspomnianej noty może świadczyć o poważaniu, jakim kardynał darzył ówczesnego Naczelnego Dowódcę Wojsk Polskich. Nie było tajemnicą,

\footnotetext{
118 M. Kornat, Papież Pius XI i Polska w dobie totalitaryzmów i kryzysu wersalskiego 19331939, „Studia nad Faszyzmem i Zbrodniami Hitlerowskimi” 2008, 30, s. 225.

119 Cyt. za: J. Jurkiewicz, op. cit., s. 79.

120 Cyt. za: J. Pietrzak, op. cit., s. 265.

121 J. Dębiński, Kościót, s. 233.

122 A. Friszke, op. cit., s. 278-279.
} 
że A. Ratti wykazywał się niechęcią w stosunku do kard. A. Kakowskiego ${ }^{123}$. Jest to o tyle niezrozumiałe, że kard. A. Kakowski wszedł do Rady Regencyjnej, mając aprobatę Episkopatu oraz Stolicy Apostolskiej. Jako jej przewodniczący, jak sam przyznał, starał się „prowadzić politykę kurii rzymskiej, politykę kunktatorstwa"124. W 1933 r. kard. A. Kakowski przebywając w Rzymie, powiedział ambasadorowi Skrzyńskiemu: „ład i porządek w kraju istnieje tylko dzięki Marszałkowi, toteż niepodobna zrozumieć, by wszyscy w Polsce nie odczuwali za to wdzięczności"125. Ksiądz J. Dębiński stwierdza też, że J. Piłsudski „,́́wiadomie i celowo wyróżniał kard. A. Kakowskiego, by podkreślić, że chce razem z Kościołem pracować dla dobra Polski ${ }^{126}$. Marszałek doskonale zdawał sobie sprawę $\mathrm{z}$ tego, że A. Kakowski jest do niego przychylnie nastawiony, dlatego jego bliskie relacje z nim należy raczej obliczyć na rachunek politycznych kalkulacji, tj. korzyści, jakie płynęły z ich wzajemnych, życzliwych stosunków. Z niektórymi biskupami, jak już wskazano wcześniej, stosunki J. Piłsudskiego układały się bardzo źle. Dość przy tym wspomnieć, że to jego postawa stawała się zawsze katalizatorem konfliktu, a zasadzała się głównie na jego osobistych antypatiach.

A. Kakowski poprzez swoją pozycję i autorytet stał się politycznym doradcą A. Hlonda, gdy idzie o współpracę z piłsudczykami ${ }^{127}$. Osobiste zapatrywania kard. A. Hlonda na kwestie społeczne mogą budzić pewne kontrowersje w kontekście katolickiej nauki społecznej. Prymas był skłonny przystać na pewne zmiany społeczne, pod warunkiem że nie będą one godzić w niezmienną moralność chrześcijańską. „Postępowe poglądy" biskupa należy tłumaczyć tym, że sam wywodził się z ubogiej rodziny i dorastał $\mathrm{w}$ warunkach, które trudno określić mianem zamożności. Swojego stanowiska Prymas Polski nie zmienił nawet po II wojnie światowej. Na akademii ku czci Chrystusa Króla w Poznaniu w 1945 r. mówił: „Chcemy, by Polska była krajem postępowym, najkulturalniejszym. Chcemy współpracować z poczucia katolickiego nad wprowadzeniem takiego ustroju społecznego, w którym nie byłoby ani przywilejów, ani krzywd, ani głodnych, ani bezdomnych, by w polskiej społeczności narodowej, zorganizowanej wedle nakazów sprawiedliwości i miłości bliźniego, każdy obywatel miał możliwość uczciwą pracą zapewnić sobie i rodzinie byt godny człowieka". Rozpowszechnianiu społecznej nauki

\footnotetext{
123 J. Szymański, op. cit., s. 161.

124 S. Wilk SDB, Episkopat Kościoła katolickiego w Polsce w latach 1918-1939, Lublin 1992, s. 663-664.

125 J. Szymański, op. cit., s. 163.

126 Ibidem, s. 163.

127 T. Serwatka, Koncepcje, s. 206.
} 
Kościoła miała służyć utworzona w 1933 r. „,Rada Społeczna przy Prymasie Polski"128. Analogiczny przypadek można dostrzec w przypadku bpa Józefa Teodorowicza, który z jednej strony ostro krytykował socjalizm, jako zdecydowanie przeciwstawny chrystianizmowi, z drugiej zaś dostrzegł jego zasługi, jeśli chodzi o zainteresowanie kwestią społeczną i robotniczą ${ }^{129}$.

Trudno powiedzieć, na ile wydarzenia polityczne w Polsce wpłynęły na decyzję papieża o mianowaniu A. Hlonda prymasem polski i kardynałem. Był on niewątpliwie dla Watykanu dobrym pretendentem do tego stanowiska - niezwiązany oficjalnie z żadną frakcją polityczna, był rzecznikiem interesów Watykanu w Polsce, jednak w niektórych sprawach skłonny był do pójścia na ustępstwa z rządem ${ }^{130}$. Kardynał A. Hlond unikał kontaktów z opozycją; apele abpa Sapiehy o zajęcie negatywnego stanowiska wobec rządu pozostały bez echa. Bierną postawę prymasa wobec metod politycznych stosowanych przez piłsudczyków T. Serwatka tłumaczy m.in. osobistą sympatią do J. Piłsudskiego oraz przychylnym nastawieniem Piusa XI do rządów pomajowych w Polsce ${ }^{131}$. W październiku 1926 r. kard. A. Hlond podkreślił, że „Kościół nie solidaryzuje się z żadną formą rządów i nie jest związany z żadną partią polityczną. Ale jako powiernik i stróż nauki i zasad Chrystusowych, każe zasad przestrzegać także $\mathrm{w}$ życiu publicznym ${ }^{132}$. Marszałek J. Piłsudski także imponował prymasowi po „cudzie nad Wisłą". Do Narodowej Demokracji nie miał zaufania ze względu na jej nacjonalizm, zaś Chrześcijańską Demokrację uważał za słabą. Na przeciwległym biegunie znajdowały się frakcje zdeklarowane lewicowo, takie jak PPS, PSL „Wyzwolenie” i formacje komunistyczne, które zdaniem A. Hlonda stanowiły zagrożenie dla katolicyzmu. Istniało wiele punktów zbieżnych pomiędzy stosunkiem do kraju A. Hlonda i obozu piłsudczykowskiego, takich jak walka z partyjnictwem czy też dążenie do wewnętrznej konsolidacji państwa, stąd ich wzajemne relacje były na ogół życzliwe ${ }^{133}$. Jak zauważa J. Jurkiewicz, „u podstaw sojuszu kleru z sanacją leżała wspólna wrogość wobec lewicy i to była jego ultima ratio. A. Hlond i A. Kakowski deklarowali rządowi J. Piłsudskiego lojalność i współpracę, nie ze względu na możliwość uzyskania tych czy innych koncesji, lecz w głębokim przekonaniu, że ten

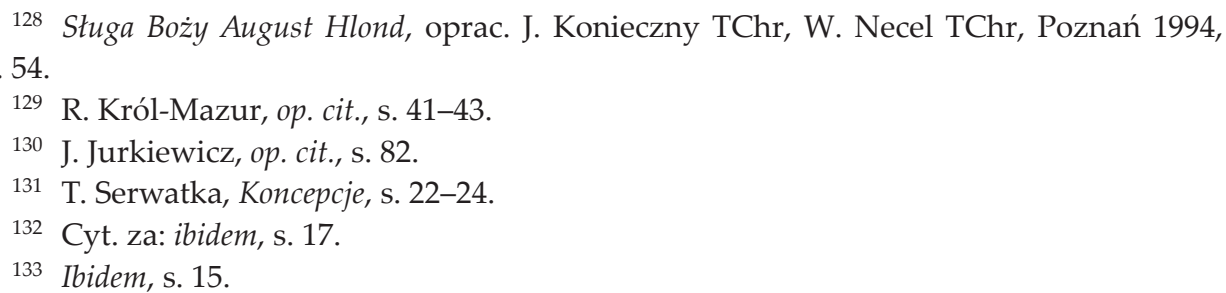


właśnie rząd będzie najskuteczniej bronić ich przed rewolucją"134. Prymas A. Hlond przebywając już poza granicami kraju, w r. 1939 także wyraził swoją solidarność z ekipą rządzącą ${ }^{135}$.

\section{DZIAŁANIA RZĄDU NA KORZYŚĆ KOŚCIOŁA}

Na pewno nie można jednak powiedzieć, że postawa kard. A. Kakowskiego i kard. A. Hlonda była naiwna i nie znajdowała żadnego uzasadnienia w poczynaniach ekipy rządzącej. J. Piłsudski optował za znormalizowanymi stosunkami z klerem, jednakże za cenę jego posłuszeństwa względem bieżącej polityki państwa ${ }^{136}$. Zdaniem ks. J. Dębińskiego Marszałek „,na pewno nie walczył z Kościołem, był raczej do niego nastawiony życzliwie". Dzięki temu nie doszło w Polsce do ostrych zatargów pomiędzy państwem a Kościołem, jak np. w Rosji czy w Niemczech $^{137}$. Porównywanie sytuacji Kościoła w Polsce do jego pozycji w III Rzeszy czy ZSRS (zapewne te właśnie kraje miał na myśli ks. J. Dębiński) wydaje się być jednak wielką przesadą. Rząd sanacyjny zdobywał się także na ustawodawstwo bardziej przychylne Kościołowi. Warto wspomnieć chociażby o rozporządzeniu ministra wyznań religijnych z 9 grudnia 1926 r. („okólnik Bartla”), który na barki nauczycieli nakładał m.in. kontrolę praktyk religijnych $\mathrm{w}$ przypadku uczniów, takich jak obowiązek trzykrotnej spowiedzi w ciagu roku szkolnego ${ }^{138}$. W tym samym roku minister spraw wojskowych wydał akt, który miał za zadanie ułatwić pracę kapelanów wojskowych ${ }^{139}$. „Okólnik Bartla” nie został jednak pozytywnie przyjęty we wszystkich kręgach związanych ze szkolnictwem. Za jego zniesieniem 8 maja 1927 r. manifestowała grupa działaczy oświatowych ${ }^{140}$ wywodząca się głównie ze środowiska Związku Nauczycielstwa Polskiego, któremu w prasie katolickiej tamtych czasów zarzucano dążenie do całkowitego zeświecczenia oświaty, przy czerpaniu wzoru m.in. z działalności i postulatów francuskiej masonerii ${ }^{141}$. Jednocześnie na jej łamach zwracano niejednokrotnie uwagę na to, że sanacyjni publicyści

\footnotetext{
134 J. Jurkiewicz, op. cit., s. 97.

135 J. Szymański, op. cit., s. 162.

136 W.T. Kulesza, op. cit., s. 86.

137 J. Dębiński, Józef, s. 106.

138 R. Polak, Religia rzymskokatolicka w szkołach II Rzeczypospolitej, Lublin 2007, s. 174.

139 Ibidem, s. 87.

140 M. Jakubiak, Relacje państwo - Kościół katolicki na tle polityki oświatowo-wychowawczej sanacji, Warszawa 2016, s. 44.

141 S. Radosz, Lewoy tor polityki szkolnej, „Przegląd Katolicki” 1935, 12, s. 182.
} 
popierający obóz rządowy wykluczają możliwość pogodzenia wychowania państwowego z wychowaniem religijnym spod szyldu Kościoła katolickiego ${ }^{142}$. Mniej lub bardziej wiarygodne teorie spiskowe natrafily $\mathrm{w}$ tym przypadku na podatny grunt, biorąc pod uwagę to, jak wielu sanacyjnych polityków należało do lóż masońskich.

14 i 17 kwietnia 1926 r. odbyła się konferencja MWRiOP, w której udział wzięli biskupi H. Przeździecki, A. Szelążek i S. Łukomski. Ustalono, że pracownicy kuratoriów oświaty będący wizytatorami nauki religii w szkołach powinni być wyznania katolickiego. Naukę religii na terenie swoich diecezji mieli nadzorować biskupi. Niniejsze postanowienia obowiązywały także po zamachu majowym ${ }^{143}$. W dniach 30 listopada - 1 grudnia 1926 r. odbył się zjazd metropolitów Kościoła katolickiego w Polsce. Prasa opozycyjna donosiła, jakoby w trakcie jego obrad podjęto decyzje godzące $w$ polską rację stanu. W tych okolicznościach kard. A. Hlond złożył wizytę ministrowi sprawiedliwości Meysztorowi, który zastępował chorego premiera, oświadczając mu: „Prymas Polski, deklarując szczerą lojalność episkopatu wobec państwa i Rządu, oświadcza, że Episkopat pragnie harmonijnej współpracy z władzami państwowymi i zgodnie ze swym posłannictwem działać stale dla dobra ojczyzny, nie wchodząc w politykę partyjna, którą prasa niektórych kierunków niesłusznie Episkopatowi podsuwa"144.

Po zamachu majowym, jeszcze za życia J. Piłsudskiego, ukazał się szereg aktów normatywnych, które regulowały sytuację społeczno-prawną Kościoła, w dużym względzie na jego korzyść. Kościół katolicki w Polsce poprzez działalność duszpasterską w wojsku uzyskał w nim pewne wpływy; duchowni i zakonnicy przebywający w więzieniach i w aresztach zapobiegawczych uzyskali specjalne przywileje; osoby duchowne i zakonnicy uzyskali znaczne ułatwienia, jeśli chodzi o wpisywanie własności do ksiąg hipotecznych. Prawa sprzeczne z konkordatem zostały ostatecznie zniesione w 1931 i 1933 r. Ostatnim akcentem przychylnego nastawienia rządu do Kościoła pod względem normatywnym było rozporządzenie prezydenta z 1934 r., które wyjęło spod prawa o stowarzyszeniach organizacje katolickie, jednakowoż stwarzając im dogodne warunki do funkcjonowania ${ }^{145}$.

Kościół zdawał sobie sprawę z tego, że mimo wszystko J. Piłsudski odegrał wielką rolę w odzyskaniu przez Polskę niepodległości. Legenda

142 Zob. np. J. Rawicz, Kościót a wychowanie państwowe, „Przegląd Katolicki” 1935, 12, s. 179 .

143 Ibidem, s. 170.

144 Cyt. za: J. Jurkiewicz, op. cit., s. 85-86.

145 Ibidem, s. 87. 
Marszałka ożyła niewątpliwie po jego zasługach w wojnie polsko-bolszewickiej. Także Kościół katolicki doceniał jego rolę w tym zakresie. W 1920 r. w Międzyrzeczy celebrowano mszę świętą w intencji Naczelnika Państwa za odniesione zwycięstwo ${ }^{146}$. Biskup Henryk Przeździecki także poniekąd doceniał zasługi J. Piłsudskiego dla dobra kraju. W liście pasterskim z 7 października 1928 r. wydanym „z okazji dziesięciolecia niepodległości Polski" spośród organizacji, które czynnie brały udział w drodze do niepodległości polski, na pierwszym miejscu wymienił „legiony Komendanta"147.

Kościół akceptował oficjalne uroczystości państwowe, które były powszechnie aprobowane, takie jak 15 sierpnia czy 11 listopada. Uroczystości o charakterze stricte sanacyjnym były jednak czasem nieuznawane; wśród nich można wymienić obchody imienin Marszałka J. Piłsudskiego. Głoszenie kazań o wydźwięku politycznym w dniu wspomnienia liturgicznego św. Józefa było dla przykładu zakazane w diecezji wileńskiej. Księża o orientacji propiłsudczykowskiej czasem jednak bojkotowali ten zakaz $^{148}$. Uroczystości patriotyczne w II Rzeczypospolitej cieszyły się wielkim uznaniem. Szczególną uwagę przywiązywano do celebrowania święta odzyskania niepodległości. Władze państwowe zwracały się do księży o sprawowanie nabożeństwa w tym czasie, ci z kolei spełniali ich życzenie $^{149}$. Prezydent Ignacy Mościcki brał udział w pielgrzymkach na Jasną Górę, a na Zamku Królewskim w Warszawie odbywały się czasem spektakularne uroczystości kościelne ${ }^{150}$. Władze państwowe przekazywały także czasem własne pieniądze na rzecz potrzeb poszczególnych parafii ${ }^{151}$.

\section{ESKALACJA KONFLIKTU PO ŚMIERCI MARSZAŁKA}

Do konfliktu na linii Kościół-obóz piłsudczykowski dochodziło jednak także wielokrotnie $\mathrm{w}$ związku $\mathrm{z}$ obchodami żałobnymi po śmierci Marszałka. Wielu duchownych wyrażało obawy co do tego, czy J. Piłsudski odszedł pojednany z Bogiem, jednak były to wątpliwości na wyrost,

\footnotetext{
146 S. Kalinowski, Organizacje społeczne i prasa w akcji promocji legendy Józefa Piłsudskiego w powiecie radzyńskim w okresie II Rzeczypospolitej, "Radzyński Rocznik Humanistyczny” 2013, 11, s. 32.

147 Ibidem.

148 W. Śleszyński, Polityka państwa a Kościót katolicki na ziemiach północno-wschodnich II Rzeczypospolitej, w: Między Wilnem a Białymstokiem. 50-lecie śmierci Arcybiskupa Romualda Jałbrzykowkiego, Białystok 2007, s. 25.

149 G. Chajko, op. cit., s. 356.

150 J. Szymański, op. cit., s. 165.

151 S. Bylina, op. cit., s. 149.
} 
gdyż tuż przed śmiercią został zaopatrzony sakramentami świętymi ${ }^{152}$. Ksiądz Jasionowski został zwolniony z funkcji prefekta kontraktowego po tym, jak odmówił wpisania się do księgi kondolencyjnej w związku ze śmiercią J. Piłsudskiego. Tykociński ksiądz prefekt Antoni Kochański skrytykował w szkole noszenie czarnych opasek, które na znak żałoby po śmierci Marszałka nosili uczniowie. Duchowny na wniosek prokuratora sądu okręgowego został aresztowany i osadzony w Łomży ${ }^{153}$.

Bardzo napięta sytuacja była w diecezji kieleckiej, gdzie bp Augustyn Łosiński na wieść o odejściu Marszałka z tego świata nie wywiesił flagi na znak żałoby oraz zabronił bić w dzwony ${ }^{154}$. Kielecka kuria po tych zajściach, oraz $\mathrm{w}$ odpowiedzi na plotki o rzekomym zawieszeniu w czynnościach duszpasterskich kieleckiego biskupa, wydała specjalne oświadczenie, w którym stwierdziła, że „brednie te zostały częściowo bezkrytycznie zaczerpnięte $z$ brukowych piśmideł, które już daleko przed zgonem śp. Marszałka bez najmniejszego powodu oczerniały Dostojnika Kościoła Diecezji Kieleckiej". Zwrócono też uwagę na to, że w całej diecezji za duszę Marszałka „odprawiono niezliczoną ilość mszy świętych”, jednocześnie odcinając się od pogłosek, jakoby bp Łosiński miał nie pozwolić dzwonić w dzwony kościelne w dniu pogrzebu J. Piłsudskiego ${ }^{155}$. Jednak dzwony w diecezji kieleckiej na znak żałoby narodowej faktycznie zaczęły bić dopiero kilka dni później, po interwencji papieża Piusa XI, który zażyczył sobie, aby żałoba po śmierci J. Piłsudskiego obowiązywała we wszystkich diecezjach w Polsce ${ }^{156}$. Postawa kieleckiego biskupa spotkała się z ostrą reakcją ze strony obozu sanacyjnego, ponownie domagano się usunięcia ordynariusza z piastowanego urzędu, w Kielcach urządzano wiece i demonstracje, w czasie których padały slogany typu „precz z kacapem!”, a wojewoda kielecki miał zarzucać biskupowi brak patriotyzmu i grozić stryczkiem. W siedzibie kurii wielokrotnie wybijano szyby w oknach i obrzucano ją pojemnikami z atramentem. Diecezję kielecką spotkały represje ze strony państwa - wstrzymano przede wszystkim wypłatę środków finansowych na utrzymanie świątyń i prowadzenie działalności duszpasterskiej przewidzianą w konkordacie ${ }^{157}$.

Biskup Łosiński był jednak jednym z oponentów Marszałka, zwłaszcza po 1926 r. i jak podkreśla jego biografista Grzegorz Liebrecht: „będąc

\footnotetext{
152 J. Wolny, op. cit., s. 141; J. Dębiński, Kościót, s. 231.

153 T. Białous, op. cit., s. 154.

154 J. Dębiński, Kościót, s. 231.

155 Wyjaśnienie w sprawie napaści na biskupa Łosińskiego, „Przegląd Katolicki” 1935, 25,

156 G. Liebrecht, Biskup Augustyn Łosiński. Ordynariusz Diecezji Kieleckiej w latach 19101937, Kielce 2018, s. 242.

157 Ibidem, s. 244-252.
} s. 418 . 
również typem samotnika o mocnej konstrukcji psychicznej, od samego początku wrogo odnosił się do tego, który po maju 1926 roku objął pełnię władzy w Polsce" ${ }^{158}$. Eskalacja tej wrogości po zamachu majowym wyrażała się m.in. poprzez ignorowanie święta 11 listopada, które uważał za sanacyjne i lewicowe, a także zarządzeń dotyczących organizacji nabożeństw czy kwestii ubezpieczeń społecznych osób świeckich zatrudnionych w kurii diecezjalnej. Kielecki biskup był jedynym ordynariuszem obrządku łacińskiego, który nie wziął udziału w zebraniu Komitetu Biskupów w Poznaniu 1 grudnia 1926 r., dotyczącym sytuacji politycznej w kraju, a które zostało zwołane przez arcybiskupa A. Hlonda. Władze państwowe próbowały kontrolować antysanacyjną postawę biskupa, czemu służyła prośba o przesyłanie listów pasterskich do MWRiOP przed ich ogłoszeniem oraz podjęcie zabiegów w Stolicy Apostolskiej mających na celu usunięcie go z piastowanego stanowiska - obydwa afronty były bezskuteczne ${ }^{159}$. Za kieleckim biskupem wstawili się bp Przeździecki i inni członkowie Episkopatu, organizując wsparcie finansowe dla bpa Łosińskiego, co świadczy o jego dużym poparciu i poważaniu w Episkopacie Polski ${ }^{160}$.

Biskup łomżyński Stanisław Łukomski został posądzony o zbyt zdawkowe uczczenie Marszałka po jego śmierci, pomimo iż zarządził on specjalne nabożeństwa żałobne, które zostały zrealizowane, włącznie z odprawieniem przez niego samego specjalnej mszy świętej w katedrze, która trwała dwie godziny. Do dzwonnicy katedralnej w Łomży włamywali się kilkakrotnie przedstawiciele Związku Legionistów, Polskiej Organizacji Wojskowej, Bezpartyjnego Bloku Współpracy z Rządem (BBWR) i dzwonili w dzwony. Policjanci po zgłoszeniu sprawy, zamiast interweniować w obronie czci należnej miejscu świętemu, poczęli na polecenie miejscowych władz spektakularnie obstawiać pałac biskupi ${ }^{161}$. W nocy z 21 na 22 maja 1935 r. w lokalu BBWR, pod przewodnictwem płk. Romanowicza, odbyło się zebranie przedstawicieli związków i organizacji zawodowych $\mathrm{w}$ Łomży i powiecie łomżyńskim. W ramach uchwały zdecydowano „zwrócić się do Władz Naczelnych z prośbą o usunięcie księdza biskupa S. Łukomskiego z zajmowanego stanowiska w związku ze zgonem śp. Marszałka Piłsudskiego" i sporządzono wniosek, w którym postulowano ustanowienie nowego ordynariusza w diecezji łomżyńskiej, pod którą podpisały się 32 organizacje. Za biskupem stanęli murem

\footnotetext{
158 Ibidem, s. 198-199.

159 Ibidem, s. 200-203.

160 Idem, Działalność filantropijna biskupa kieleckiego Augustyna Łosińskiego w latach 19101937, „Studia Muzealno-Historyczne” 2009, 1, s. 74.

161 W. Guzewicz, Internowanie, s. 273-274.
} 
diecezjanie. Wedle pisma diecezjalnego „Sprawa Katolicka” napłynęło 100 tys. podpisów w obronie bpa S. Łukomskiego ${ }^{162}$. W sierpniu przybył do bpa dyrektor Departamentu Wyznań Franciszek Potocki, gdyż większość wystawianych pod jego adresem zarzutów była nieprawdziwa, w związku z czym biskup domagał się natychmiastowego uzdrowienia sytuacji ${ }^{163}$. Ostatecznie sprawa zakończyła się kompromitacją obozu rządzącego, a premier Walery Sławek poinformował bpa S. Łukomskiego o planowanych zmianach personalnych $\mathrm{w}$ miejscowej administracji ${ }^{164}$.

Jednak najbardziej znanym epizodem, jeśli chodzi o animozje związane z pośmiertnym kultem J. Piłsudskiego, był tzw. konflikt wawelski, gdy jego ciało sprowadzono na Wawel. Źle zabalsamowane szczątki zaczęły się psuć, czuć było olejki oraz fetor rozkładającego się ciała. Katedra stanowiła przejście do krypty św. Leonarda, stąd szczątki Marszałka znalazły się $\mathrm{w}$ niedogodnym położeniu. Zdarzało się, że przy trumnie swojego przełożonego oficerowie wojskowi urządzali libacje alkoholowe ${ }^{165}$. Jak podkreśla ks. Jerzy Wolny: „zaraz po pogrzebie władze państwowe rozpoczęły akcję organizowania nawiedzeń, przede wszystkim młodzieży szkolnej, ze wszystkich stron Polski, dla oddania hołdu zmarłemu marszałkowi. Było to następne ogniwo w rozwoju kultu zmarłego wodza narodu. W sanktuarium narodowym, w dostojnej katedrze wawelskiej młodzież w długim oczekiwaniu na chwilę oddania hołdu zmarłemu załatwiała swoje potrzeby fizjologiczne po kątach, toteż w kościele rozchodził się nieprzyjemny zapach"166. Lekarz wojskowy zajęty był tam dokonywaniem poprawek źle zabalsamowanych zwłok, w wyniku których w krypcie roznosiła się niemiła woń, z kolei Wincenty Witos wspominał, że „w krypcie, w której leżały zwłoki Piłsudskiego, znajdowano w prawie każdy dzień flaszki po wypitej wódce, papiery, szmaty, niedopałki papierosów"167. Ze względu na niedogodne położenie krypty, do której jedyna droga prowadziła z bocznej nawy katedry, abp Sapieha w czerwcu 1937 r. podjął brzemienną w skutki decyzję o przeniesieniu ciała J. Piłsudskiego z krypty św. Leonarda do krypty pod Wieżą Srebrnych Dzwonów ${ }^{168}$. Niedługo po tym wydarzeniu w Polsce rozpętała się tzw. akcja antysapieżyńska, nazywana inaczej „konfliktem wawelskim”, która

\footnotetext{
162 T. Białous, op. cit., s. 157.

163 Ibidem, s. 159.

164 W. Guzewicz, Internowanie, s. 277.

165 M. Rożek, op. cit., s. 73.

166 J. Wolny, Konflikt Wawelski, w: Księga Sapieżyńska, t. 2, Kraków 1986, s. 115.

167 Ibidem, s. 120 z przyp.

168 Krypta św. Leonarda ze względu na swoje położenie była od początku traktowana przez abpa Sapiehę za tymczasowe miejsce spoczynku szczątków marszałka.
} 
przybrała charakter ogólnonarodowy; pisano o niej nawet w zagranicznych mediach ${ }^{169}$. Premier gen. F. Sławoj Składkowski w ramach protestu ostentacyjnie podał się do dymisji, która jednak nie została przyjęta przez prezydenta. Domagano się odebrania abpowi Sapieże wszelkich nadanych mu odznaczeń, a nawet pozbawienia go obywatelstwa polskiego i opuszczenia przezeń kraju, pojawiały się także po raz kolejny postulaty modyfikacji konkordatu. W trwającej ponad miesiąc akcji przez całą Polskę przetoczyła się jednocześnie fala protestów; ucierpiał między innymi Pałac Biskupów Krakowskich, w którym powybijano szyby ${ }^{170}$. O zaistniałej sytuacji został nawet poinformowany papież Pius XI, który jako mediatora w zaistniałym sporze wyznaczył nuncjusza abpa Filippo Cortesiego ${ }^{171}$. Także media nie pozostawiały na arcybiskupie suchej nitki. Ostatecznie konflikt został zażegnany, a nowe miejsce pochówku Marszałka usankcjonowane. Przez swoją nieugiętą postawę abp Sapieha otrzymał przydomek Księcia Niezłomnego ${ }^{172}$.

Prasa katolicka mimo wszystko tuż po śmierci J. Piłsudskiego odnosiła się do niego z wielkim szacunkiem. Obok zasług dla ojczyzny podkreślano, że Marszałek doceniał rolę, jaką odegrał Kościół katolicki w dziejach państwa i narodu, zwracając uwagę na jego przyjazne stosunki $\mathrm{z}$ niegdysiejszym nuncjuszem apostolskim $\mathrm{w}$ Polsce, a ówczesnym papieżem Piusem XI, wkład w zawarcie konkordatu ze Stolicą Apostolską oraz cześć dla NMP Ostrobramskiej ${ }^{173}$. Z podobną estymą wypowiadano się na temat późniejszego pogrzebu J. Piłsudskiego, którego nazywano „Wodzem Armii”"174.

Po śmierci Marszałka idee sanacji zaczęły się zbliżać w pewnym stopniu do doktryny katolickiej. Władze cywilne w stosunku do Kościoła nastawione były coraz bardziej pozytywnie, co ten drugi oczywiście dostrzegł. Niektórzy piłsudczycy pozbywali się z czasem swoich antyklerykalnych poglądów i odnosili się do Episkopatu z życzliwą przychylnością; tak było na przykład w przypadku Kazimierza Świtalskiego, który już w latach dwudziestych nawiązał pośrednie kontakty z kard. A. Hlondem,

\footnotetext{
169 M. Rożek, op. cit., s. 75.

170 Ibidem, s. 126-129.

171 Ibidem, s. 76-77.

172 Arcybiskup Sapieha swoją niezłomność i charakter udowadniał jeszcze wielokrotnie. W czasie II wojny światowej szacunkiem darzyli go częściowo sami Niemcy; podczas okupacji hitlerowskiej doprowadził on dwukrotnie do konferencji plenarnych Episkopatu Polski w siedzibie Kurii Metropolitarnej, znajdującej się tuż obok Wawelu, gdzie rezydował Hans Frank. Zob. J. Chrobaczyński, Compiègne 1940. Klęska Francji w koncepcjach i recepcji społeczeństwa polskiego, Kraków 2010, s. 253-254.

173 U trumny pierwszego Marszałka Polski Odrodzonej, „Przegląd Katolicki” 1935, 21, s. 345.

174 Na marginesie pogrzebu Marszałka, „Przegląd Katolicki” 1935, 22, s. 361.
} 
kard. A. Kakowskim, a także przedstawicielami polskiej chadecji i jako premier optował za uregulowaniem sprawy konkordatu w myśl postulatów stawianych przez Kościół ${ }^{175}$. Tymczasem biskupi, których dotąd określano jako przeciwników Marszałka, zbliżyli się do Chrześcijańskiej Demokracji oraz Frontu Morges ${ }^{176}$.

Niewątpliwie ewenementem w historii obozu sanacyjnego była ewolucja po śmierci J. Piłsudskiego w kierunku nacjonalistycznym i szukania porozumienia z Narodową Demokracją; tworzyły się w nim jednocześnie pewne inklinacje antysemickie na polu gospodarczym i kulturowym. Zdaniem A. Ajnenkiela Obóz Zjednoczenia Narodowego, sanacyjną organizację polityczną tworzoną po śmierci Marszałka, począwszy od 1937 r., budowano na zasadach hierarchicznych przypominających rozwiązania totalitarne ${ }^{177}$. Dały wówczas znać o sobie brak spójności ideowej i miałkość ideologii piłsudczykowskiej, w której nigdy nie wypracowano spójnego programu politycznego ${ }^{178}$. OZN podejmował wysiłki zmierzające do tego, aby przyciągnąć kler do siebie, jednak Kościół pozostał na zachowawczym stanowisku, podkreślając swoją daleko posuniętą apolityczność. W deklaracji OZN czytamy: „Naród polski związał się duchowo na progu swego cywilizacyjnego rozwoju z katolickim Kościołem i stwierdził niejednokrotnie przynależność do niego bohaterstwem przelanej krwi. Naród polski, w olbrzymiej większości katolicki, przywiązany jest do swego Kościoła, dlatego Kościół katolicki winien być otoczony należytą opieką"179. Mieczysław Niedziałkowski, działacz OZN, miał powiedzieć: „bądźmy szczerzy: trzeba zmobilizować plebanię dla obozu P. Koca, bo plebania to wielki czynnik"180.

Kościół katolicki jednak, pomimo wysiłków czynionych przez drugą stronę, nie dał się wprzęgnąć $\mathrm{w}$ tę na poły utopijną wizję państwa, co potwierdza jego negatywny stosunek do nacjonalizmu ${ }^{181}$. KAP ograniczyła się jedynie do ogłoszenia krótkiego komunikatu, w którym podnoszono, że Kościół opowiada się za podejmowaniem wysiłków, których zadaniem jest doprowadzenie do „prawdziwej konsolidacji, zgody i pokoju

175 T. Serwatka, Kazimierz, s. 61, 108.

176 K. Krasowski, Biskupi, s. 136-137.

177 A. Ajnenkiel, op. cit., s. 543-547.

178 W. Paruch, Obóz Piłsudczykowski (1926-1939), w: Więcej niż niepodległość. Polska myśl polityczna 1918-1939, red. J. Jachymek, W. Paruch, Lublin 2005, s. 76-79.

179 Cyt. za: J. Szymański, op. cit., s. 168.

180 T. Jędruszczak, Stanowisko społeczeństwa i opozycji wobec powstania Obozu Zjednoczenia Narodowego, „Najnowsze Dzieje Polski. Materiały i Studia z Okresu 1914-1939” 1961, 4, s. 204.

181 Zob. J. Majchrowski, Obóz Zjednoczenia Narodowego a Kościół katolicki, „Więź” 1976, 12, s. $119-128$. 
w Polsce". Zwracano w nim uwagę na ponadpartyjność kleru, choć znaczna jego część $w$ dalszym ciągu sympatyzowała $\mathrm{z}$ endecją. Łomżyńska Kuria Biskupia wydała deklarację, w której czytamy, że „apel do zgody i do podania rąk to wielkie słowo. Wyciagając jednak rękę do zgody, trzeba dać innym możność podania nam ręki również"182.

\section{PODSUMOWANIE I UWAGI KOŃCOWE}

Przedstawiciele obozu piłsudczykowskiego w wielu kwestiach wyrażali radykalne poglądy, które stały w ewidentnej sprzeczności z katolicką doktryną społeczną. Często prowadzili niemoralne życie i wielu z nich należało do lóż masońskich oraz optowało wprost za ideologią antyklerykalną. Sytuacja zaogniła się po 1926 r., kiedy to nastąpiły rządy autorytarne w Polsce. Duchowni zostali poddani inwigilacji, a przestrzeganie konkordatu przez państwo pozostawiało wiele do życzenia. Nieco inny obrót przybrały wydarzenia po śmierci Marszałka J. Piłsudskiego, kiedy to rząd ewoluował w kierunku zbliżonym do opcji katolicko-narodowej, jednak sytuacja na linii obóz piłsudczykowski - Kościół katolicki do samego końca istnienia II Rzeczypospolitej pozostawała napięta. Mimo wszystko, sanacyjny obóz rządzący wolał widzieć w Kościele i duchowieństwie katolickim raczej sojusznika, nie wroga, stąd podejmował czasem takie działania, które wobec Kościoła były jak najbardziej przychylne. Wydaje się jednak, że ta postawa była podyktowana czystym pragmatyzmem oraz chęcią podniesienia poparcia społecznego dla bieżącej polityki państwa i systemu rządów.

Indyferentyzm religijny J. Piłsudskiego i jego popleczników wzbudzał konsternację wśród przedstawicieli polskiego kleru, funkcjonującego przecież w państwie, którego większość mieszkańców była przywiązana do Kościoła katolickiego i wyznawanych przez niego wartości. Kult osoby J. Piłsudskiego, a także niepodległego państwa polskiego, zdawał się przesłaniać i odciągać od tej właściwej sfery sacrum. Życie duchowe nie znosi pustki, stąd tuż za wschodnią granicą ${ }^{183}$, a od 1933 r. także za zachodnią ${ }^{184}$, tworzono systemy polityczne mające charakter quasi-religijny, ze szczególnie zaakcentowanym kultem jednostki. W Polsce wspomniany kult został jeszcze bardziej zintensyfikowany po śmierci Marszałka, co również prowadziło do konfliktów z katolickim klerem. Duchowni zdawali sobie sprawę z tego, że polscy komuniści początkowo

\footnotetext{
182 T. Jędruszczak, op. cit., s. 207.

183 Zob. M. Kula, Religiopodobny komunizm, Kraków 2003.

184 Zob. A. Kmak-Pamirska, Religia w czasach Trzeciej Rzeszy, Toruń 2010.
} 
poparli zamach majowy, a granica zachodząca pomiędzy komunizmem a socjalizmem nie była wówczas tak wyraźnie zaznaczona jak współcześnie, dodatkowo nakładała się na nią obojętność czy nawet niechęć sanacji do nauki społecznej Kościoła katolickiego, nie tylko zresztą w sferze czysto ekonomicznej. Polscy duchowni zdawali się nie dostrzegać w Marszałku osoby zdecydowanie wrogo nastawionej do komunizmu, jak to czynił papież Pius XI po wojnie polsko-bolszewickiej z 1920 r., której był naocznym świadkiem.

Odziedziczona po rewolucji francuskiej oraz dziewiętnastowiecznych zrywach rewolucyjnych niechęć Kościoła do bezprawnych przewrotów politycznych i następujących po nich laickich, czasem tyrańskich rządów, wyraziła się także w potępieniu przez dużą część polskiego Episkopatu zamachu majowego, który na dodatek $\mathrm{w}$ ich mniemaniu - nie bez racji - nastąpił dopiero wtedy, gdy sytuacja polityczna w Polsce zaczęła się stabilizować. Polska prasa katolicka jednakowoż odnotowywała martyrologię Kościoła katolickiego w czasie wojny domowej w Hiszpanii (1936-1939) ${ }^{185}$, a wcześniej docierały do naszego kraju echa wojny domowej w Meksyku (1926-1929) i walki tamtejszych Cristeros o chrześcijański porządek społeczny ${ }^{186}$. Ta ostatnia dodatkowo rozgrywała się właśnie wtedy, gdy sytuacja polityczna w Polsce uległa zaognieniu, tragizmu dodawał też fakt, że to masoneria sterowała tamtejszą polityką wymierzoną przeciwko Kościołowi. Tymczasem ogromna liczba polskich polityków spod rządów sanacji należała do lóż wolnomularskich, masoneria była też wówczas tematem bardziej nośnym i częściej podnoszonym w kręgach kościelnych niż współcześnie.

Poparcie, jakiego duża część duchowieństwa udzielała endecji, znajdującej się na przeciwległym biegunie polskiej sceny politycznej, wynikała z jednej strony z bliższości jej programu politycznego - przynajmniej po 1926 r. - katolickiej nauce społecznej, z drugiej zaś także z osobistych zapatrywań politycznych polskiego kleru. Do Stronnictwa Narodowego w młodości należało wielu przyszłych polskich biskupów, takich jak Józef Teodorowicz, Walenty Dymek, Arkadiusz Lisiecki czy Stanisław Łukomski, współpracowali z nią także inni przyszli biskupi. Wiązało się to, rzecz jasna, z ich późniejszymi działaniami i wypowiedziami politycznymi ${ }^{187}$. Stąd ówczesna scena polityczna w Polsce i jej relacje z klerem ulegały

185 W. Opioła, Stanowisko polskiej prasy katolickiej wobec wojny domowej w Hiszpanii 19361939. Analiza dyskursu medialnego, „Media, Kultura, Społeczeństwo” 2010, 1, 5, s. 5-19.

186 M. Kula, K. Smolana, Echa meksykańskiego konfliktu religijnego lat 1926-1929 w Polsce, „Ameryka Łacińska. Kwartalnik Analityczno-Informacyjny” 2009, 17, 4 (66), s. 21-33.

187 B. Grott, Wpływ myśli katolickiej na myśl prawicy polskiej w XX wieku, w: Od nacjonalistycznych konfrontacji do porozumienia europejskiego. Rola Kościołów w dziejowej drodze Niemiec i Polski w XIX w XX wieku, red. G. Besier, Wałbrzych 2004, s. 111. 
pewnemu rodzajowi polaryzacji, a jeszcze bardziej podsycał ją fakt, że idea rozdziału Kościoła od państwa - choć widać było już wówczas jej zalążki - wciąż nie była oficjalnie uznana w doktrynie katolickiej, dając duchownym wiele przestrzeni, jeśli chodzi o zaangażowanie polityczne.

\section{REFERENCES (BIBLIOGRAFIA)}

\section{Printed sources (Źródła drukowane)}

Łosiński A., Chrześcijańska miłość ojczyzny i praca narodowa, Gniezno 1919.

Nacjonalizm a katolicyzm. Opinie biskupów, uczonych, polityków i publicystów współczesnych (tekst z roku 1927), tłum. J. Puzynianek, Krzeszowice 2007.

Pius XI, encyklika Quadragesimo anno.

Żongołłowicz B., Dzienniki 1930-1936, oprac. D. Zamojska, Warszawa 2004.

\section{Press (Prasa)}

Buczko A., Nowa Konstytucja Rzeczypospolitej, „Przegląd Katolicki” 1935, 21.

Korzonkiewicz J., Wobec polityki i wyborów, „Przegląd Katolicki” 1930, 36.

Kozubski Z., Czy istnieją wskazania lekarskie na spędzenie płodu?, „Przegląd Katolicki” 1930, 7. Na marginesie pogrzebu Marszałka, „Przegląd Katolicki” 1935, 22.

Nowy kodeks a małżeństwo, „Przegląd Katolicki” 1930, 8.

Podoleński S., W sprawie kodyfikacji prawa matżeńskiego w Polsce, "Przegląd Powszechny” 1926, 169, 505.

Radosz S., Lewy tor polityki szkolnej, „Przegląd Katolicki” 1935, 12.

Rawicz J., Konstytucja 1935 r., „Przegląd Katolicki” 1935, 13.

Rawicz J., Kościót a wychowanie państwowe, „Przegląd Katolicki” 1935, 12.

U trumny pierwszego Marszałka Polski Odrodzonej, „Przegląd Katolicki” 1935, 21.

Urban J., Nasz stosunek do socjalizmu, „Przegląd Powszechny” 1927, 174.

Wyjaśnienie w sprawie napaści na biskupa Łosińskiego, „Przegląd Katolicki” 1935, 25.

\section{Studies (Opracowania)}

Ajnenkiel A., Polska po przewrocie majowym. Zarys dziejów politycznych Polski 1926-1939, Warszawa 1980.

Białous T., Biskup Stanisław Kostka Łukomski (1874-1948). Pasterz niezłomny, Rajgród 2010.

Bylina S., Relacje państwo - Kościót katolicki na południowym Podlasiu w II Rzeczypospolitej, Drohiczyn 2013.

Chajko G., Arcybiskup Bolesław Twardowski (1864-1944). Metropolita lwowski obrzadku łacińskiego, Rzeszów 2010.

Chajn L., Wolnomularstwo i Piłsudski w 1921 r., „Zeszyty Historyczne” 1981, 55.

Chrobaczyński J., Compiègne 1940. Klęska Francji w koncepcjach i recepcji społeczeństwa polskiego, Kraków 2010.

Czajowski J., Kardynat Adam Stefan Sapieha, Wrocław 1997.

Danek A., Wspótpraca miesięcznika "Pro Christo" ze środowiskiem Bolesława Piaseckiego jako wynik "planu penetracyjnego" Falangi, w: Nacjonalizmy różnych narodów. Perspektywa politologiczno-religioznawcza, red. B. Grott, O. Grott, Kraków 2012.

Dębiński J., Józef Piłsudski a Kościót katolicki w Polsce w latach 1918-1935, w: Józef Piłsudski wobec Europy i wybranych zagadnień wewnętrznych Drugiej Rzeczypospolitej (1918-1935). W 70 rocznicę śmierci, red. M. Wojciechowski, Z. Karpus, Włocławek-Toruń 2007. 
Dębiński J., Kościót rzymskokatolicki wobec przewrotu majowego i rządów sanacji, w: Zamach stanu Józefa Pitsudskiego i jego konsekwencje w interpretacjach polskiej myśli politycznej XX wieku, red. Z. Karpus, G. Radomski, W. Wojdyła, Toruń 2008.

Engelgard J., Religia i polityka - Józef Teodorowicz i Narodowa Demokracja w latach 1902-1918, w: Teodorowicz. Mówca i patriota. Materiaty z konferencji naukowej, red. T. Skoczek, Warszawa 2015.

Friszke A., O ksztatt niepodległej, Kraków 1989.

„Godziemba”, Konflikt wawelski w 1937 roku, http://www.jpilsudski.org/artykuly-historyczne-pilsudski/epizody-z-zycia-jozefa-pilsudskiego/item/2025-konflikt-wawelski-w-1937-roku [dostęp: 4 V 2018].

Grott B., Wpływ myśli katolickiej na myśl prawicy polskiej w XX wieku, w: Od nacjonalistycznych konfrontacji do porozumienia europejskiego. Rola Kościołów w dziejowej drodze Niemiec i Polski w XIX w XX wieku, red. G. Besier, Wałbrzych 2004.

Grzybowski M.M., Kardynat II Rzeczypospolitej Aleksander Kakowski 1862-1938, „Notatki Płockie" 2013, 58, 1 (234).

Guzewicz W., Internowanie biskupa Stanisława Łukomskiego, czyli o obchodach żałobnych Marszałka Piłsudskiego w diecezji łomżyńskiej, „Studia Ełckie” 2014, 16, 3.

Guzewicz W., Duchowieństwo diecezji łomżyńskiej w II Rzeczypospolitej, Lublin 2003.

Hrycek M., Wątki antysemickie w "Kurierze Łódzkim” w okresie międzywojennym, „Folia Litteraria Polonica" 2012, 17, 3.

Jakubiak K., Kategoria państwa w ksztattowaniu koncepcji wychowania państwowego w II Rzeczypospolitej, w: Wychowanie a polityka. Mity i stereotypy w polskiej myśli społecznej XX wie$k u$, red. W. Wojdyła, Torun 2000.

Jakubiak M., Relacje państwo - Kościół katolicki na tle polityki oświatowo-wychowawczej sanacji, Warszawa 2016.

Jędruszczak T., Stanowisko społeczeństwa i opozycji wobec powstania Obozu Zjednoczenia Narodowego, „Dzieje Najnowsze” 1961, 4, 204.

Jurkiewicz J., Watykan a Polska w okresie międzywojennym 1919-1939, Warszawa 1960.

Kalinowski S., Organizacje społeczne i prasa w akcji promocji legendy Józefa Piłsudskiego w powiecie radzyńskim w okresie II Rzeczypospolitej, "Radzyński Rocznik Humanistyczny” 2013, 11.

Kawalec K., Przewrót majowy jako etap narastania w polskim życiu politycznym tendencji skrajnych, „Studia nad Autorytaryzmem i Totalitaryzmem” 2011, 33.

Kmak-Pamirska A., Religia w czasach Trzeciej Rzeszy, Toruń 2010.

Kolasa W.M., Kierunki badań nad historia prasy polskiej 1918-1939, cz. 1, Tendencje rozwojowe, typologia, „Rocznik Historii Prasy Polskiej” 2011, 14, 1-2 (27-28).

Kornat M., Papież Pius XI i Polska w dobie totalitaryzmów i kryzysu wersalskiego 1933-1939, „Studia nad Faszyzmem i Zbrodniami Hitlerowskimi” 2008, 30.

Krasowski K., Biskupi katoliccy II Rzeczypospolitej. Stownik biograficzny, Poznań 1996.

Krasowski K., Między Warszawa a Watykanem. Episkopat Polski wobec rząu i Stolicy Apostolskiej 1918-1939, w: Szkice z dziejów papiestwa, t. 1, red. I. Koberdowa, J. Tazbir, Warszawa 1989.

Król-Mazur R., Działalność polityczna abp. Józefa Teofila Teodorowicza w latach 1888-1923, Kraków 2013.

Kruczkowski L., Dlaczego jestem socjalistą?, Warszawa 1938.

Kula M., Smolana K., Echa meksykańskiego konfliktu religijnego lat 1926-1929 w Polsce, „Ameryka Łacińska. Kwartalnik Analityczno-Informacyjny" 2009, 17, 4 (66).

Kula M., Religiopodobny komunizm, Kraków 2003. 
Kulesza W., Koncepcje ideowo-polityczne obozu rzadzacego w Polsce w latach 1926-1935, Wrocław-Warszawa-Kraków-Gdańsk-Łódź 1985.

Leszczyński P.A., Stosunki państwo - Kościót w koncepcjach oraz praktyce rządów obozu piłsudczykowskiego, Gorzów Wielkopolski 2008.

Liebrecht G., Biskup Augustyn Łosiński. Ordynariusz Diecezji Kieleckiej w latach 1910-1937, Kielce 2018.

Liebrecht G., Działalność filantropijna biskupa kieleckiego Augustyna Łosińskiego w latach 19101937, „Studia Muzealno-Historyczne” 2009, 1.

Macała J., Polska katolicka w myśli politycznej II RP, Zielona Góra 2004.

Majchrowski J., Obóz Zjednoczenia Narodowego a Kościót katolicki, „Więź” 1976, 12.

Nitecki P., Socjalizm, komunizm i ewangelizacja, Lublin 1998.

Opioła W., Stanowisko polskiej prasy katolickiej wobec wojny domowej w Hiszpanii 1936-1939. Analiza dyskursu medialnego, "Media, Kultura, Społeczeństwo” 2010, 1, 5.

Osiński Z., Janusza Jędrzejewicza droga do kariery w obozie piłsudczykowskim, „Annales Universitatis Mariae Curie-Skłodowska. Sectio F, Historia" 2006, 61.

Paczkowski A., Prasa w życiu politycznym Drugiej Rzeczypospolitej, „Dzieje Najnowsze” 1978, 10, 3.

Pałka D., Warunki dialogu Kościoła katolickiego z Żydami w II Rzeczypospolitej, „Poznańskie Studia Teologiczne" 2005, 18.

Paruch W., Myśl polityczna formacji piłsudczykowskiej w Polsce (1926-1939) - cechy podstawowe, „Annales Universitatis Mariae Curie-Skłodowska. Sectio K, Politologia” 2014, 21, 2.

Paruch W., Obóz Piłsudczykowski (1926-1939), w: Więcej niż niepodległość. Polska myśl polityczna 1918-1939, red. J. Jachymek, W. Paruch, Lublin 2005.

Pest C., Kardynat Edmund Dalbor (1869-1926). Pierwszy Prymas Polski odrodzonej, Poznań 2004.

Pietrzak J., Czy kard. August Hlond był zwolennikiem sanacji? w: Kościół w II Rzeczypospolitej, red. Z. Zieliński, S. Wilk, Lublin 1980.

Pietrzak J., Nuncjatura Achillesa Ratti w Polsce w latach 1918-1921 w świetle wspomnień o niej, w: Vade Nobiscum, red. Z. Brzozowska et al., Łódź 2009.

Polak R., Religia rzymskokatolicka w szkołach II Rzeczypospolitej, Lublin 2007.

Prochwicz J., Arcybiskup Stanistaw Gall (1865-1942). Biskup Polowy Wojsk Polskich, Warszawa 2018.

Radosik R., Stereotyp masona w twórczości Skamandrytów, „Ars Regia. Czasopismo Poświęcone Myśli i Historii Wolnomularstwa" 2010, 12, 19.

Roszkowski W., Najnowsza historia Polski 1914-1945, Warszawa 2003.

Rożek M., Kardynał Sapieha, Kraków 2007.

Sadowski M. CSsR, Mit powstańczej legendy kard. Albina Dunajezwskiego, „Analecta Cracoviensia" 2014, 46.

Seniów J., W kręgu pitsudczyków. Poglądy ideowo-polityczne „Gazety Polskiej” (1929-1939), Kraków 1998.

Serwatka T., Kazimierz Świtalski (1886-1962). Biografia polityczna, Warszawa 2009,

Serwatka T., Koncepcje społeczno-polityczne Prymasa polski Augusta Hlonda (1926-1948), Poznań 2006.

Stuga Boży August Hlond, oprac. J. Konieczny TChr, W. Necel TChr, Poznań 1994.

Stanulewicz M., Prawo własności w nauczaniu episkopatu II Rzeczypospolitej, „Czasopismo Prawno-Historyczne" 2012, 64.

Synowiec A., W kręgu publicystyki Józefa Putka - spór z Kościołem katolickim, „Studia Historyczne" 2014, 57, 2. 
Szczurowski R., Socjaliści w polskiej publicystyce katolickiej 1878-1918, Kraków 2001.

Szymański J., Stosunek Watykanu do spraw polskich za czasów II Rzeczypospolitej 1919-1939, Radom 1982.

Śleszyński W., Polityka państwa a Kościół katolicki na ziemiach pótnocno-wschodnich II Rzeczypospolitej, w: Między Wilnem a Biatymstokiem. 50-lecie śmierci Arcybiskupa Romualda Jatbrzykowkiego, Białystok 2007.

Trajdos T.M., Uwagi o działalności politycznej i przekonaniach arcybiskupa Józefa Teodorowicza, w: Teodorowicz. Mówca i patriota. Materiaty z konferencji naukowej, red. T. Skoczek, Warszawa 2015.

Waingertner P., Wolnomularstwo a Kościót katolicki w II Rzeczypospolitej. Kontrowersje i polemi$k i$, „Acta Universitatis Lodziensis. Folia Historica” 1995, 52.

Warszawski J., Studia nad wyznaniowościa religijna marszałka Józefa Piłsudskiego, Londyn 1978.

Wilk S. SDB, Episkopat Kościoła katolickiego w Polsce w latach 1918-1939, Lublin 1992.

Wolny J., Konflikt Wawelski, w: Księga Sapieżyńska, t. 2, Działalność kościelna i narodowa Adama Stefana Sapiehy, red. J. Wolny, Kraków 1986.

Wysocki W., Konterfekt religijny Marszałka, „Periodyk Naukowy Akademii Polonijnej” 2015, $2,13$.

Zwoliński A., Katolik i polityka, Kraków 1999.

Zwoliński A., Polskie ścieżki masonerii, Kraków 2014.

Zwoliński A., Wokót masonerii, Kraków 1993.

\section{NOTA O AUTORZE}

Przemysław Sołga - doktorant historii na Uniwersytecie Pedagogicznym w Krakowie, gdzie pod kierunkiem prof. Mariusza Wołosa finalizuje pracę na temat wizerunku nacjonalizmu w świetle publicystyki katolickiej Drugiej Rzeczypospolitej. Zainteresowania naukowe: historia Kościoła, historiologia, politologia religii. Publikował w takich czasopismach, jak: „Dzieje Najnowsze”, „Res Gestae”, „Historyka”, „Teologia i Człowiek”, „Sensus Historiae". 